\title{
Highly Stable and Efficient Light-Emitting Electrochemical Cells Based on Cationic Iridium Complexes Bearing Arylazole Ancillary Ligands
}

\author{
Marta Martínez-Alonso, ${ }^{\mathrm{a}}$ Jesús Cerdá, ${ }^{\mathrm{b}}$ Cristina Momblona, ${ }^{\mathrm{b}}$ Antonio Pertegás, ${ }^{\mathrm{b}}$ José M. Junquera- \\ Hernández, ${ }^{\mathrm{b}}$ Aránzazu Heras, ${ }^{\mathrm{a}}$ Ana M. Rodríguez, ${ }^{\mathrm{c}}$ Gustavo Espino, ${ }^{*, \mathrm{a}}$ Henk Bolink ${ }^{*, \mathrm{~b}}$, and Enrique \\ Ortí, *, \\ ${ }^{a}$ Departamento de Química, Facultad de Ciencias, Universidad de Burgos, Plaza Misael Bañuelos s/n, 09001 Burgos, Spain \\ ${ }^{b}$ Instituto de Ciencia Molecular, Universidad de Valencia, Catedrático José Beltrán 2, 46980 Paterna, Spain \\ ${ }^{c}$ Departamento de Química Inorgánica, Orgánica y Bioquímica, Facultad de Químicas, Universidad de Castilla-La Mancha, \\ Avda. Camilo J. Cela 10, 13071 Ciudad Real, Spain
}

Keywords: Cationic iridium(III) complexes, arylazole ligands, DFT calculations, electroluminescence, LECs.

\begin{abstract}
A series of bis-cyclometalated iridium(III) complexes of general formula $\left[\operatorname{Ir}(\mathrm{ppy})_{2}\left(\mathrm{~N}^{\wedge} \mathrm{N}\right)\right]\left[\mathrm{PF}_{6}\right]\left(\mathrm{ppy}^{-}=2\right.$-phenylpiridinate; $\mathrm{N}^{\wedge} \mathrm{N}=$ 2-(1H-imidazol-2-yl)pyridine (1), 2-(2-pyridyl)benzimidazole (2), 1-methyl-2-pyridin-2-yl-1H-benzimidazole (3), 2-(4'thiazolyl)benzimidazole (4), and 1-methyl-2-(4'-thiazolyl)benzimidazole (5)) is reported, and their use as electroluminescent materials in light-emitting electrochemical cell (LEC) devices is investigated. [2] $\left[\mathrm{PF}_{6}\right]$ and $[3]\left[\mathrm{PF}_{6}\right]$ are orange emitters with intense unstructured emission around $590 \mathrm{~nm}$ in acetonitrile solution. $[1]\left[\mathrm{PF}_{6}\right],[4]\left[\mathrm{PF}_{6}\right]$, and $[5]\left[\mathrm{PF}_{6}\right]$ are green week emitters with structured emission bands peaking around $500 \mathrm{~nm}$. The different photophysical properties are due to the effect that the structure of the ancillary ligand has on the nature of the emitting triplet state. Whereas the benzimidazole unit stabilizes the LUMO and gives rise to a ${ }^{3} \mathrm{MLCT} /{ }^{3} \mathrm{LLCT}$ emitting triplet in $[2]\left[\mathrm{PF}_{6}\right]$ and $[3]\left[\mathrm{PF}_{6}\right]$, the presence of the thiazolyl ring produces the opposite effect in $[4]\left[\mathrm{PF}_{6}\right]$ and $[5]\left[\mathrm{PF}_{6}\right]$ and the emitting state has a predominant ${ }^{3} \mathrm{LC}$ character. Complexes with ${ }^{3} \mathrm{MLCT} /{ }^{3} \mathrm{LLCT}$ emitting triplets give rise to LEC devices with luminance values one order higher than complexes with ${ }^{3} \mathrm{LC}$ emitting states. Protecting the imidazole $\mathrm{N}-\mathrm{H}$ bond with a methyl group, as in complexes $[3]\left[\mathrm{PF}_{6}\right]$ and $[5]\left[\mathrm{PF}_{6}\right]$, determine that the emissive properties become more stable. $[3]\left[\mathrm{PF}_{6}\right]$ leads to outstanding LECs with simultaneously high luminance $\left(904 \mathrm{~cd} \mathrm{~m}^{-2}\right)$, efficiency $\left(9.15 \mathrm{~cd} \mathrm{~A} \mathrm{~A}^{-1}\right)$, and stability (lifetime over 2500 hours).
\end{abstract}

\section{INTRODUCTION}

Energy efficient devices for lighting and display applications are highly demanded. During the last years, organic lightemitting diodes (OLEDs) ${ }^{1,2,3}$ have been widely used in energy efficient displays, but their high manufacturing costs make them not suitable for a wide use in lighting. Light-emitting electrochemical cells (LECs) ${ }^{4,5}$ have emerged as potential candidates for light-emitting devices with promising energy savings and high-quality lighting. LECs are composed of a single active layer of an ionic organic or organometallic semi- conductor placed between two electrodes. Due to their simple single-layer structure and their easy processing from solution, LECs are compatible with low-cost manufacturing ${ }^{6}$ and constitute a good alternative to OLEDs for lighting. A wide range of organic materials has been used in the manufacture of LECs. ${ }^{7,8,9,10,11}$ However, the best efficiencies have been achieved with ionic transition-metal complexes (iTMCs), ${ }^{12,13,14,15}$ and, in particular, with iridium(III) complexes due to their efficient spin-orbit coupling, which ideally allows to harvest $100 \%$ of the excitons generated in the device. $^{16}$ 
The optical and emitting properties of Ir-iTMCs can be easily modulated by chemically modifying the structure of the ligands attached to the central $\operatorname{Ir}($ III) core. Nowadays, a wide variety of complexes has been designed and used to manufacture LEC devices covering the whole visible spectrum, ${ }^{16,17,18,19}$ with high efficiencies, ${ }^{20,21,22}$ top lifetimes, ${ }^{23,24,25}$ and short turnon times. ${ }^{26,27,28}$ However, it is still to be found a complex that allows the fabrication of a device that reunites all those characteristics and becomes suitable for real-life lighting applications.

One desirable key feature for LEC devices is a long lifetime, which should be in the range of a few thousands hours if LECs have to compete with commonly used lighting devices. A long device lifetime is related to a high complex stability. The most common strategy to achieve such high stability has been the inclusion of bulky hydrophobic ligands to protect the coordination center. ${ }^{23,29}$ However, bulky groups are known to slow down the migration of the ions in the device inducing long turn-on times. ${ }^{30,31}$ Hence, there is still room to explore new strategies and ligands in search for higher performances and stabilities.

In this work, we introduce a series of new complexes with arylazole-based ancillary ligands without bulky groups, and use them to prepare LEC devices trying to reach high stabilities without affecting the turn-on times. Arylazoles present some advantages as ancillary ligands to prepare iridium iTMCs. They are either commercially available or easily prepared and offer a large deal of structural and chemical diversity, since a variety of aryl and azole entities (imidazole, oxazole, thiazole, etc.) can be used. In addition, the enhanced electron-donating nature of the azole rings, due to the presence of one additional heteroatom with one or two lone electron pairs $(\mathrm{N}-\mathrm{H}, \mathrm{O}$, or $\mathrm{S})$, tends to destabilize the lowestunoccupied molecular orbital (LUMO), enlarging the optical gap and blue-shifting the light emitted in comparison to complexes bearing classical 2,2'-bipyridine (bpy)-type ligands. Arylazole ligands can therefore be used to fine tuning the photophysical and chemical properties of Ir-iTMCs. ${ }^{32}$ In particular, the imidazole ring can furthermore be functionalized through the reactive $\mathrm{N}-\mathrm{H}$ bond.

The electroluminescence properties of Ir-iTMCs bearing arylazole units as cyclometalating ligands have been widely investigated in LECs. ${ }^{33,34,35,36,37}$ In contrast, few examples of IriTMCs with arylazole-based ancillary ligands have been tested in LECs. He et al. ${ }^{38}$ described LEC devices using a family of Ir-iTMCs incorporating functionalized imidazole-type ancillary ligands with peak external quantum efficiencies up to $6.1 \%$, a maximum luminance of $395 \mathrm{~cd} \mathrm{~m}^{-2}$, and different emission colors depending on the complex. One year later, the same group reported a blue-green LEC with a pyrazole-type ancillary ligand and a peak external quantum efficiency of $7.6 \%$, although at a much lower luminance, less than $20 \mathrm{~cd}$ $\mathrm{m}^{-2}$. ${ }^{39}$ In both cases, the devices exhibited long turn-on times from several minutes to hours and a poor device stability under constant voltage operation. More recently, Choe and col. have reported and characterized LECs based on aryl-imidazole ancillary ligands exhibiting high brightness and color tunability, although no study of the time-response characteristics is reported. ${ }^{40,41,42,43}$

In this work, the complexes $[\mathbf{1}]\left[\mathrm{PF}_{6}\right]-[\mathbf{5}]\left[\mathrm{PF}_{6}\right]$ shown in Figure 1 have been synthesized, characterized, and employed to develop new LEC devices. Their general formula is
$\left[\operatorname{Ir}\left(\mathrm{C}^{\wedge} \mathrm{N}\right)_{2}\left(\mathrm{~N}^{\wedge} \mathrm{N}\right)\right]\left[\mathrm{PF}_{6}\right]$, where the $\mathrm{C}^{\wedge} \mathrm{N}$ ligand always corresponds to 2-phenylpyridinate (ppy ${ }^{-}$) and the ancillary $\mathrm{N}^{\wedge} \mathrm{N}$ ligand is 2-(1H-imidazol-2-yl)pyridine (pyim), 2-(2pyridyl)benzimidazole (pybim), 1-methyl-2-pyridin-2-yl-1Hbenzimidazole (pyMebim), 2-(4'-thiazolyl)benzimidazole (thiabendazole, tbz), and 1-methyl-2-(4'thiazolyl)benzimidazole (Metbz). The complexes were selected to study: i) the importance that the protection of the $\mathrm{N}-\mathrm{H}$ bond of the imidazole has on the stability of the complexes, and ii) the influence that the substitution of the pyridyl group by the more electron-donating thiazolyl group has on the photophysical properties. The effect of the ancillary ligand on the electrochemical and photophysical properties was investigated and further analyzed with the help of density functional theory (DFT) calculations. The electroluminescence properties of the complexes were investigated in LEC devices operated under pulsed driving conditions. Complex [2] $\left[\mathrm{PF}_{6}\right]$ was previously known, ${ }^{44}$ but it has not been used in LEC devices yet. Complex [3] $\left[\mathrm{PF}_{6}\right]$ and its use in LECs under voltage scan (current density and luminance) were reported but, to the best of our knowledge, no investigation of the device performance vs. time was performed. ${ }^{40}$

\section{RESULTS AND DISCUSSION}

\section{Synthesis and Characterization}

The complexes depicted in Figure 1 were prepared following the Nonoyama protocol ${ }^{45}$ in two steps. In the first step, the chloro-bridged dimeric iridium complex $\left[\operatorname{Ir}(\mu-\mathrm{Cl})(\mathrm{ppy})_{2}\right]_{2}$ was isolated from the reaction between $\operatorname{IrCl}_{3} \cdot x \mathrm{H}_{2} \mathrm{O}$ and 2phenylpyridine (Hppy). In the second step, the corresponding ancillary $\mathrm{N}^{\wedge} \mathrm{N}$ ligand was introduced in the coordination sphere of $\operatorname{Ir}(\mathrm{III})$ through a bridge splitting reaction, and then, an anion exchange protocol was applied to isolate the $\mathrm{PF}_{6}{ }^{-}$ salt, as outlined in Scheme 1. The complexes were isolated in good yields as racemic mixtures $(\Delta, \Lambda)$ of yellow-to-orange solids that are soluble in common organic solvents.

All the complexes were characterized by multinuclear NMR, IR, and mass spectroscopy and by elemental analysis. 2D NMR experiments were conducted to assign all the signals in the ${ }^{1} \mathrm{H}$ (Figure S1 and S2 in the Supporting Information) and ${ }^{13} \mathrm{C}\left\{{ }^{1} \mathrm{H}\right\}$ NMR spectra. 
<smiles>c1ccc(-c2ncc[nH]2)nc1</smiles>

pyim

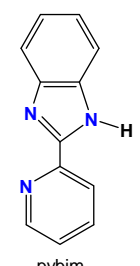

pybim

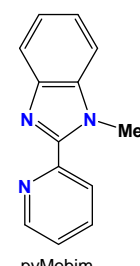

pyMebim

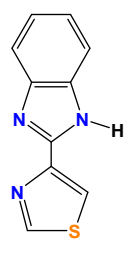

tbz

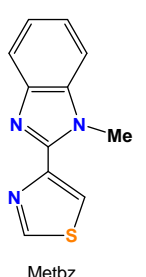

Complexes $[1]\left[\mathrm{PF}_{6}\right]-[5]\left[\mathrm{PF}_{6}\right]$

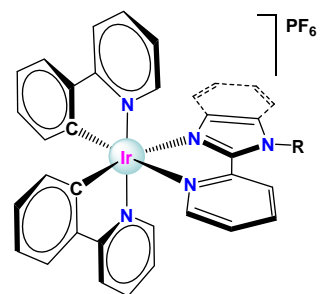

$\mathrm{N}^{\wedge} \mathrm{N}=$ pyim, $[1]\left[\mathrm{PF}_{6}\right]$

$\mathrm{N}^{\wedge} \mathrm{N}=$ pybim, $[2]\left[\mathrm{PF}_{6}\right]$ $\mathrm{N}^{\wedge} \mathrm{N}=$ pyMebim, [3][PF 6$]$

Figure 1. Arylazole ligands used in this work and chemical structures of the synthesized iridium(III) complexes $[\mathbf{1}]\left[\mathrm{PF}_{6}\right]-$ $[5]\left[\mathrm{PF}_{6}\right]$.

Scheme 1. Second step in the synthetic route for complexes $[\mathbf{1}]\left[\mathrm{PF}_{6}\right]-[\mathbf{5}]\left[\mathrm{PF}_{6}\right]$.

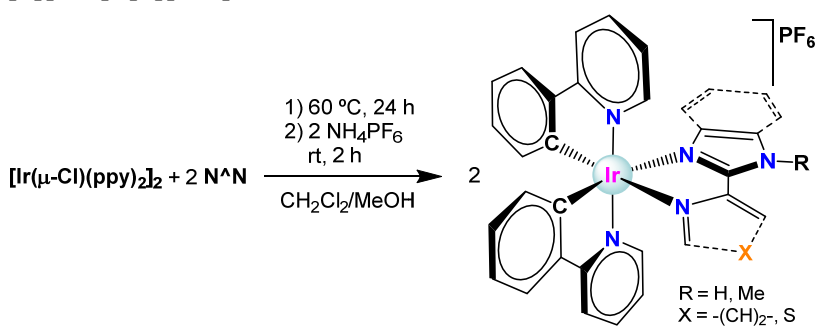

[1] $\left[\mathrm{PF}_{6}\right]-[5]\left[\mathrm{PF}_{6}\right]$

The following main features are inferred from the analysis of the NMR spectra recorded in DMSO- $\mathrm{d}_{6}$ at $25{ }^{\circ} \mathrm{C}$ :

(1) The asymmetric nature of the synthesized compounds ( $C 1$ symmetry) renders the two phenylpyridinate ligands in every complex inequivalent and thus the corresponding ${ }^{1} \mathrm{H}$ and ${ }^{13} \mathrm{C}\left\{{ }^{1} \mathrm{H}\right\}$ NMR spectra show two different sets of signals for the $\mathrm{C}^{\wedge} \mathrm{N}$ donors.

(2) The 2D noesy spectra of some complexes exhibit interligand and inter-ring crosspeaks very useful in the assignation of all the signals (Figure S2).

(3) Complexes $[1]\left[\mathrm{PF}_{6}\right],[2]\left[\mathrm{PF}_{6}\right]$, and $[4]\left[\mathrm{PF}_{6}\right]$ exhibit a broad peak between 14 and $15 \mathrm{ppm}$ for its $\mathrm{N}-\mathrm{H}$ proton, whereas complexes with $\mathrm{N}-\mathrm{Me}$ groups display a sharp singlet at 4.45 or $4.31 \mathrm{ppm}$ for $[3]\left[\mathrm{PF}_{6}\right]$ and $[5]\left[\mathrm{PF}_{6}\right]$, respectively.

The ${ }^{13} \mathrm{C}\left\{{ }^{1} \mathrm{H}\right\}$ NMR spectra are fully consistent with the structural features ascertained by ${ }^{1} \mathrm{H}$ NMR. In the FAB+ MS spectra, the characteristic sets of peaks for the cationic fragments $\left[\operatorname{Ir}\left(\mathrm{C}^{\wedge} \mathrm{N}\right)_{2}\left(\mathrm{~N}^{\wedge} \mathrm{N}\right)\right]^{+}$and $\left[\operatorname{Ir}\left(\mathrm{C}^{\wedge} \mathrm{N}\right)_{2}\right]^{+}$are found, with isotopic patterns compatible with the presence of iridium, whereas in the FT-IR spectra typical diagnostic bands are observed for the $\mathrm{PF}_{6}{ }^{-}$counteranion (see the Supporting Information).

The thermal stability of complexes $[\mathbf{1}]\left[\mathrm{PF}_{6}\right]-[\mathbf{5}]\left[\mathrm{PF}_{6}\right]$ was investigated by thermogravimetric analysis (TGA) under nitrogen flow. All the complexes are thermally stable with decomposition temperatures $\left(T_{\mathrm{d}}\right.$, corresponding to $5 \%$ weight loss) all over $300{ }^{\circ} \mathrm{C}$ (Figure S3). Interestingly, complexes with $\mathrm{N}-\mathrm{Me}$ groups are more stable than those with $\mathrm{N}-\mathrm{H}$ groups (for instance, $T_{\mathrm{d}}=306$ and $386 \mathrm{C}$ for $[2]\left[\mathrm{PF}_{6}\right]$ and $[3]\left[\mathrm{PF}_{6}\right]$, respectively).

\section{Crystal Structures by X-ray Diffraction}

Single crystals suitable for $\mathrm{X}$-ray diffraction analysis were obtained for $[4]\left[\mathrm{PF}_{6}\right]$ and $[5]\left[\mathrm{PF}_{6}\right]$ by slow diffusion of $n$ hexane into a solution of $[4]\left[\mathrm{PF}_{6}\right]$ in $\mathrm{CH}_{3} \mathrm{CN} / \mathrm{CH}_{2} \mathrm{Cl}_{2}$ and by slow evaporation of a solution of [5] $\left[\mathrm{PF}_{6}\right]$ in $\mathrm{CH}_{2} \mathrm{Cl}_{2}$. Both complexes crystallize in the orthorhombic Pbca space group. The ORTEP diagrams for the asymmetric units are shown in Figure 2. Selected bond lengths and angles with estimated standard deviations are gathered in Table S1 in the Supporting Information, and relevant crystallographic parameters are given in Table S2. For both complexes, the corresponding unit cell consists of four pairs of the two possible enantiomers $(\Lambda$ and $\Delta$ ), which result from the helical chirality inherent to trisbidentate octahedral metal complexes. Indeed, the cationic complexes adopt a pseudo octahedral geometry around the iridium center with the expected cis-C,C and trans-N,N disposition for the ppy $^{-}$ligands. The ancillary $\mathrm{N}^{\wedge} \mathrm{N}$ ligands show $\mathrm{N}-\mathrm{Ir}-\mathrm{N}$ bite angles of $76.1(1)^{\circ}$ (for tbz in [4] $\left[\mathrm{PF}_{6}\right]$ ) and $75.9(1)^{\circ}$ (for Metbz in $[5]\left[\mathrm{PF}_{6}\right]$ ), in agreement with those previously reported for five-membered iridacycles in similar complexes. ${ }^{46,47}$ The cyclometalated $\mathrm{C}^{\wedge} \mathrm{N}$ ligands have also standard values $\left(\sim 80^{\circ}\right)$ for the $\mathrm{C}-\mathrm{Ir}-\mathrm{N}$ bite angles. In both compounds, the 3D crystal architecture is built on the foundation of hydrogen bonding contacts and anion- $\pi$ interactions in which the $\mathrm{PF}_{6}^{-}$anions occupy a central position (Figure S4). Furthermore, both crystal structures show dimeric entities derived from $\pi-\pi$ stacking interactions involving the benzimidazole units of two vicinal cation complexes. Conspicuously, these $\pi-\pi$ interactions are hampered by the presence of the $\mathrm{N}-\mathrm{Me}$ group in $[5]\left[\mathrm{PF}_{6}\right]$, and hence they are very weak relative to the analogous interactions in $[4]\left[\mathrm{PF}_{6}\right]$, where the centroid-centroid distance is shorter, 3.58 vs $3.87 \AA$, (see Table S3 and Figures S5 and S6).

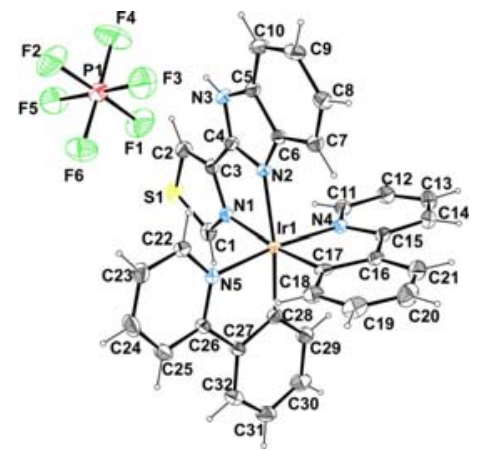




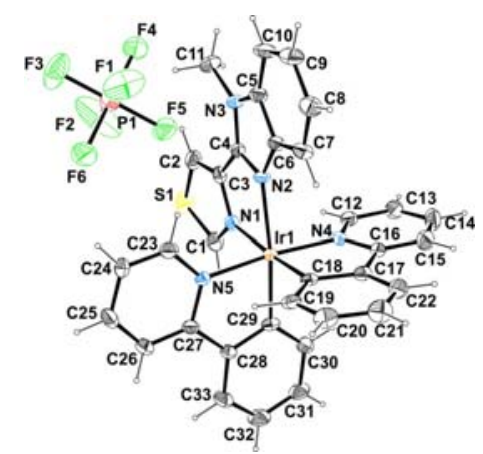

Figure 2. ORTEP diagrams for the asymmetric unit of compounds $(\Lambda)$ - $[4]\left[\mathrm{PF}_{6}\right]$ (top) and $(\Lambda)-[5]\left[\mathrm{PF}_{6}\right]$ (bottom). Thermal ellipsoids are shown at the $30 \%$ probability.

\section{Electrochemical behavior}

The redox potentials of complexes $[\mathbf{1}]\left[\mathrm{PF}_{6}\right]-[\mathbf{5}]\left[\mathrm{PF}_{6}\right]$ were experimentally determined in acetonitrile solution by cyclic voltammetry using $\left[{ }^{n} \mathrm{Bu}_{4} \mathrm{~N}\right]\left[\mathrm{PF}_{6}\right]$ as supporting electrolyte and glassy carbon as working electrode. Potentials were defined with respect to the ferrocene/ferrocenium $\left(\mathrm{Fc} / \mathrm{Fc}^{+}\right)$couple. All the electrochemical experiments were performed under argon atmosphere. The cyclic voltammogram of every $\mathrm{PF}_{6}{ }^{-}$salt shows a unique quasi-reversible oxidation peak in the anodic potential region between +0.74 and $+0.79 \mathrm{~V}$ (see Table 1 and Figure 3), which is ascribed to the oxidation of the ppy-Ir(III) environment as discussed below.

The analysis of the cathodic region allowed to establish the following trends: (a) complexes with $\mathrm{N}-\mathrm{H}$ groups in the ancillary ligand $\left([1]\left[\mathrm{PF}_{6}\right],[2]\left[\mathrm{PF}_{6}\right]\right.$, and $\left.[4]\left[\mathrm{PF}_{6}\right]\right)$ show totally irreversible peaks at $-2.20,-1.95$, and $-2.14 \mathrm{~V}$, respectively, indicating the instability of the reduced species; (b) complex $[3]\left[\mathrm{PF}_{6}\right]$, where the reactive $\mathrm{N}-\mathrm{H}$ group of pybim has been replaced with a methyl group, displays a quasi-reversible reduction peak at $-1.91 \mathrm{~V}$, which supports the higher stability of [3] $\left[\mathrm{PF}_{6}\right]$ versus $[2]\left[\mathrm{PF}_{6}\right]$; (c) complex [5] $\left[\mathrm{PF}_{6}\right]$, also with a $\mathrm{N}-\mathrm{Me}$ group, shows a reduction peak at $-2.27 \mathrm{~V}$ giving rise to the largest electrochemical gap $(3.04 \mathrm{~V})$, and its irreversible nature suggests that the reduction mechanism is different to that of $[3]\left[\mathrm{PF}_{6}\right]$. These results anticipate a very good stability for complex [3] $\left.\mathrm{PF}_{6}\right]$ under the operation conditions used in LEC devices owing to the reversible nature of the oxidation/reduction processes in which the complex is-involved in those devices.

Table 1. Cyclic Voltammetric Data Referred to $\mathrm{Fc} / \mathrm{Fc}^{+}$in Acetonitrile Solution $\left(10^{-3} \mathrm{M}\right){ }^{a}$

\begin{tabular}{|c|c|c|c|}
\hline Compound & $E^{\mathrm{ox}}{ }_{1 / 2}(\mathrm{~V})$ & $E^{\mathrm{red}}{ }_{1 / 2}(\mathrm{~V})$ & $\Delta E_{1 / 2}(\mathrm{~V})$ \\
\hline$[\mathbf{1}]\left[\mathrm{PF}_{6}\right]$ & $+0.74(\mathrm{qr})$ & $-2.20(\mathrm{ir})$ & 2.94 \\
\hline$[\mathbf{2}]\left[\mathrm{PF}_{6}\right]$ & $+0.77(\mathrm{qr})$ & $-1.95(\mathrm{ir})$ & 2.72 \\
\hline$[\mathbf{3}]\left[\mathrm{PF}_{6}\right]$ & $+0.79(\mathrm{qr})$ & $-1.91(\mathrm{qr})$ & 2.70 \\
\hline$[\mathbf{4}]\left[\mathrm{PF}_{6}\right]$ & $+0.76(\mathrm{qr})$ & $-2.14(\mathrm{ir})$ & 2.90 \\
\hline$[\mathbf{5}]\left[\mathrm{PF}_{6}\right]$ & $+0.77(\mathrm{qr})$ & $-2.27(\mathrm{ir})$ & 3.04 \\
\hline
\end{tabular}

${ }^{a}$ Measured using $0.1 \mathrm{M}\left[{ }^{n} \mathrm{Bu}_{4} \mathrm{~N}\right]\left[\mathrm{PF}_{6}\right]$ as supporting electrolyte and a scan rate of $0.15 \mathrm{~V} \mathrm{~s}^{-1}$ ( $\mathrm{qr}=$ quasi-reversible, ir $=$ irreversible).

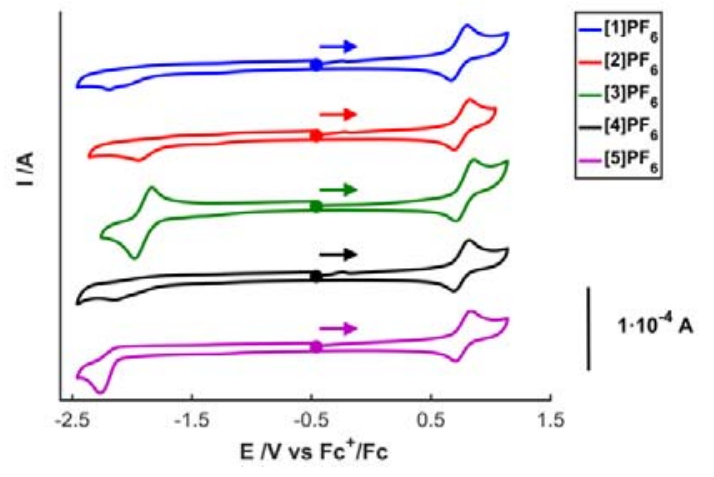

Figure 3. Cyclic voltammograms of complexes $[1]\left[\mathrm{PF}_{6}\right]-[5]\left[\mathrm{PF}_{6}\right]$ in acetonitrile solution $\left(10^{-3} \mathrm{M}\right)$, using $0.1 \mathrm{M}\left[{ }^{n} \mathrm{Bu}_{4} \mathrm{~N}\right]\left[\mathrm{PF}_{6}\right]$ as supporting electrolyte. Scan rate of $0.15 \mathrm{~V} \mathrm{~s}^{-1}$. (•) Indicates the starting $\left(\mathrm{E}_{\mathrm{i}}\right)$ and final potential $\left(\mathrm{E}_{\mathrm{f}}\right), \mathrm{E}_{\mathrm{i}}=\mathrm{E}_{\mathrm{f}}=-0.46 \mathrm{~V}$ (vs. $\mathrm{Fc} / \mathrm{Fc}^{+}$), clockwise scan.

\section{Photophysical properties}

The UV-Vis absorption spectra recorded in acetonitrile solution are displayed in Figure 4. The complexes show intense absorption bands in the UV with maxima in the range 250-350 $\mathrm{nm}$, which are mainly ascribed to spin-allowed $\pi \rightarrow \pi^{*}$ transitions of the ligands. Lower energy bands above $350 \mathrm{~nm}$ correspond to spin-allowed metal-to-ligand ( ${ }^{1}$ MLCT) and ligand-toligand charge transfer $\left({ }^{1}\right.$ LLCT) excitations, whereas the low intensity tails above $450 \mathrm{~nm}$ arise from spin-forbidden ${ }^{3} \mathrm{MLCT},{ }^{3} \mathrm{LLCT}$, and ligand-centered $\left({ }^{3} \mathrm{LC}\right)$ transitions. Compared with complex $[1]\left[\mathrm{PF}_{6}\right]$, taken as a reference, complexes [2] $\left[\mathrm{PF}_{6}\right]$ and $[3]\left[\mathrm{PF}_{6}\right]$ exhibit a more intense absorption centered around $325 \mathrm{~nm}$ due to the benzimidazole unit. Substitution of the pyridine by a thiazole ring in the $\mathrm{C}^{\wedge} \mathrm{N}$ ligand of complexes $[4]\left[\mathrm{PF}_{6}\right]$ and $[5]\left[\mathrm{PF}_{6}\right]$ blue-shifts this absorption to $300 \mathrm{~nm}$.

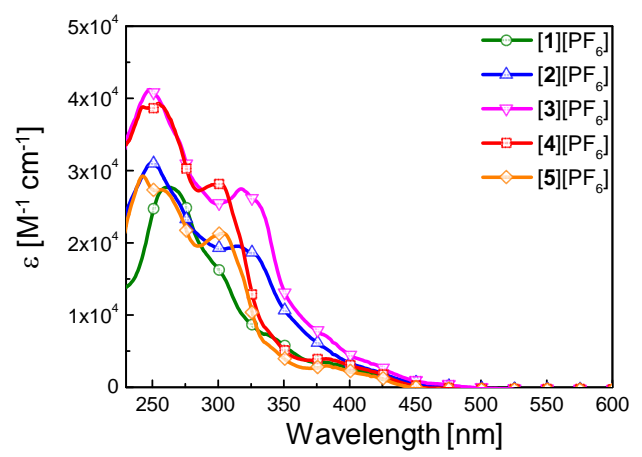

Figure 4. UV-vis absorption spectra of complexes $[1]\left[\mathrm{PF}_{6}\right]-$ $[5]\left[\mathrm{PF}_{6}\right]$ recorded in acetonitrile solution $\left(5 \times 10^{-5} \mathrm{M}\right)$.

The photoluminescence properties of complexes $[1]\left[\mathrm{PF}_{6}\right]-$ $[5]\left[\mathrm{PF}_{6}\right]$ were investigated by excitation of both deoxygenated acetonitrile solutions $\left(5 \times 10^{-5} \mathrm{M}\right.$, room temperature and $\left.77 \mathrm{~K}\right)$ and thin films with the same composition used in the active layer of LEC devices (iTMC mixed with 1-butyl-3methylimidazolium hexafluorophosphate in a 4:1 molar ratio).

Photoluminescence spectra are shown in Figure 5, and emission maxima wavelengths $\left(\lambda_{\mathrm{em}}\right)$, photoluminescence quantum 
yields $\left(\Phi_{\mathrm{PL}}\right)$, excited-state lifetimes $(\tau)$, and radiative $\left(k_{\mathrm{r}}\right)$ and non-radiative $\left(k_{\mathrm{nr}}\right)$ rate constants are summarized in Table 2. In solution, at room temperature, $[2]\left[\mathrm{PF}_{6}\right]$ and $[3]\left[\mathrm{PF}_{6}\right]$ show broad and unstructured emission bands, suggesting a large charge-transfer $(\mathrm{CT})$ character for $\mathrm{T}_{1}$ in these complexes. The CT character of the emitting state is furthermore supported by the hypsochromic shift observed in the emission bands of these complexes when the spectra are registered at $77 \mathrm{~K}$ (rigidochromic effect). ${ }^{48,49,50}$ In contrast, complexes $[\mathbf{1}]\left[\mathrm{PF}_{6}\right]$, $[4]\left[\mathrm{PF}_{6}\right]$, and $[5]\left[\mathrm{PF}_{6}\right]$ show emission profiles with some vibrational structure at room temperature that becomes more marked at $77 \mathrm{~K}$ and present no significant rigidochromic shift (Figure 5a and $\mathrm{b}$ ). This behavior is typical of emissive states with a large ${ }^{3} \mathrm{LC}$ character. ${ }^{51,52}$

The emission color of the complexes in solution goes from yellow-orange $\left([2]\left[\mathrm{PF}_{6}\right]\right.$ and $\left.[3]\left[\mathrm{PF}_{6}\right]\right)$ to blue-green $\left([\mathbf{1}]\left[\mathrm{PF}_{6}\right]\right.$, $[4]\left[\mathrm{PF}_{6}\right]$, and $\left.[5]\left[\mathrm{PF}_{6}\right]\right)$, and the peak emission wavelengths follow the trend: $[4]\left[\mathrm{PF}_{6}\right](489,508 \mathrm{~nm}) \approx[5]\left[\mathrm{PF}_{6}\right](486,508$ $\mathrm{nm})<[1]\left[\mathrm{PF}_{6}\right](516 \mathrm{~nm})<[2]\left[\mathrm{PF}_{6}\right](583 \mathrm{~nm})<[3]\left[\mathrm{PF}_{6}\right](596$ $\mathrm{nm})$ (Table 2). Hence, on changing the ancillary ligand from pyim $\left([1]\left[\mathrm{PF}_{6}\right]\right)$ to pybim $\left([2]\left[\mathrm{PF}_{6}\right]\right)$, the emission experiences a red shift, whereas the replacement of pybim $\left([2]\left[\mathrm{PF}_{6}\right]\right)$ or pyMebim $\left([3]\left[\mathrm{PF}_{6}\right]\right)$ by tbz $\left([4]\left[\mathrm{PF}_{6}\right]\right)$ or Metbz $\left([5]\left[\mathrm{PF}_{6}\right]\right)$ leads to a blue shift comparable in magnitude. The substitution of the $\mathrm{N}-\mathrm{H}$ group with a methyl in $[3]\left[\mathrm{PF}_{6}\right]$ produces a small red shift $(13 \mathrm{~nm})$ on the emission peak respect to the nonsubstituted complex $[2]\left[\mathrm{PF}_{6}\right]$ that is not observed when passing from $[4]\left[\mathrm{PF}_{6}\right]$ to $[5]\left[\mathrm{PF}_{6}\right]$.

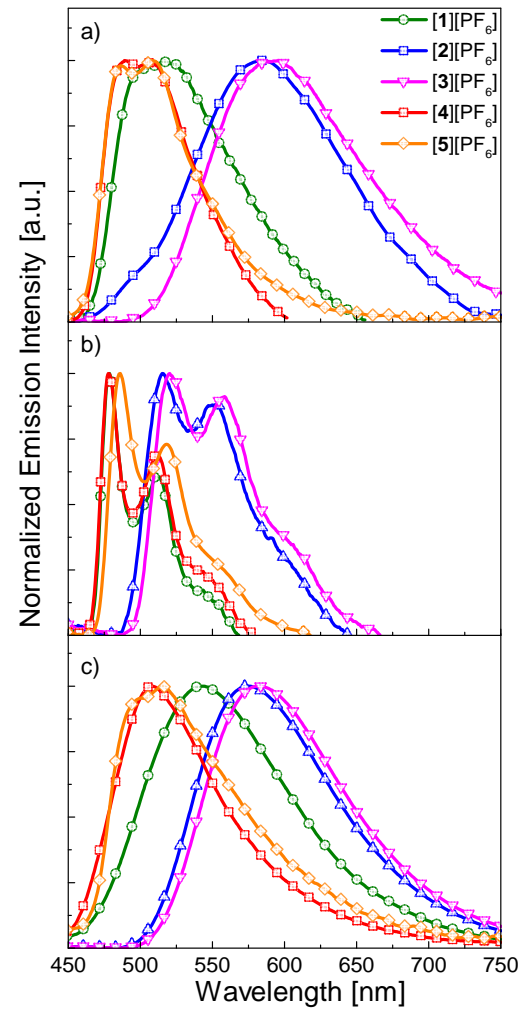

Figure 5. Photoluminescence spectra recorded at room temperature (a) and at $77 \mathrm{~K} \mathrm{(b)}$ in deaerated acetonitrile solution $\left(5 \times 10^{-5} \mathrm{M}\right)$ by excitation at $360 \mathrm{~nm}$. (c) Photoluminescence spectra registered in thin film at room temperature by excitation at $320 \mathrm{~nm}$.

Complexes $[4]\left[\mathrm{PF}_{6}\right]$ and $[5]\left[\mathrm{PF}_{6}\right]$ exhibit weak emission $\left(\Phi_{\mathrm{PL}}\right.$ $=9.0 \%$ and $4.4 \%$, respectively), in good agreement with the ${ }^{3} \mathrm{LC}$ character predicted for the emissive state in these complexes. In comparison, complexes $[2]\left[\mathrm{PF}_{6}\right]$ and $[3]\left[\mathrm{PF}_{6}\right]$ feature significantly higher $\Phi_{\mathrm{PL}}(38.5 \%$ and $39.4 \%$, respectively) in accord with the expected ${ }^{3}$ MLCT character of the emissive state that enhances the spin-orbit coupling and therefore favors the intersystem crossing. The $\Phi_{\mathrm{PL}}$ recorded for $[3]\left[\mathrm{PF}_{6}\right]$ is similar to that previously reported by Sunesh et al. ${ }^{40}$ The $\Phi_{\mathrm{PL}}$

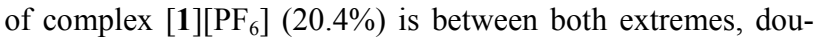
bling the values registered for the LC-type complexes and being about one half of the values recorded for the MLCTtype complexes. This suggests that the electronic description of the emissive state for $[1]\left[\mathrm{PF}_{6}\right]$ requires a deeper analysis.

Excited-state lifetimes measured in deoxygenated acetonitrile solution under an argon atmosphere are of the order of hundreds of nanoseconds (Table 2). The longest lifetime (485 ns) is recorded for complex [3][ $\left.\mathrm{PF}_{6}\right]$ and similar lifetimes around $200 \mathrm{~ns}$ are obtained for $[2]\left[\mathrm{PF}_{6}\right],[4]\left[\mathrm{PF}_{6}\right]$ and $[5]\left[\mathrm{PF}_{6}\right]$. For $[1]\left[\mathrm{PF}_{6}\right]$, a biexponential fit was used to determine an average lifetime value of $316 \mathrm{~ns}$ (see Table S4 in the Supporting Information for details). The lower $\Phi_{\mathrm{PL}}$ and shorter $\tau$ values recorded for $[4]\left[\mathrm{PF}_{6}\right]$ and $[5]\left[\mathrm{PF}_{6}\right]$ determine the higher nonradiative decay rate constants obtained for these two complexes.

The emission spectra were also recorded for amorphous thin films of the complexes with the composition used in LEC devices (Figure 5c). The spectra show a similar shape for all the complexes, and the emission maxima follow the same trend observed in solution: $[4]\left[\mathrm{PF}_{6}\right](507 \mathrm{~nm})<[5]\left[\mathrm{PF}_{6}\right](514$ $\mathrm{nm})<[1]\left[\mathrm{PF}_{6}\right](542 \mathrm{~nm})<[2]\left[\mathrm{PF}_{6}\right](574 \mathrm{~nm})<[3]\left[\mathrm{PF}_{6}\right](581$ $\mathrm{nm})$ ). Interestingly, complexes with $\mathrm{CT}$ emitting states $\left([2]\left[\mathrm{PF}_{6}\right]\right.$ and $\left.[3]\left[\mathrm{PF}_{6}\right]\right)$ exhibit their emission maxima slightly shifted to shorter wavelengths compared to solution (Table 2), whereas those with $\mathrm{LC}$ emitting states $\left([4]\left[\mathrm{PF}_{6}\right]\right.$ and $\left.[5]\left[\mathrm{PF}_{6}\right]\right)$ are red-shifted. $[\mathbf{1}]\left[\mathrm{PF}_{6}\right]$ undergoes the most drastic change in the emission maximum in passing from solution to thin film, pointing again to the existence of differences between the electronic nature of the emitting state in this complex compared with complexes $[4]\left[\mathrm{PF}_{6}\right]$ and $[5]\left[\mathrm{PF}_{6}\right]$. The thin-film emission spectra present almost no vibrational structure, probably caused by the rigidity of the solid state, and only $[5]\left[\mathrm{PF}_{6}\right]$ keeps observable vibrational bands.

Table 2. Photophysical properties of complexes $[1]\left[\mathrm{PF}_{6}\right]-[5]\left[\mathrm{PF}_{6}\right]$ in Solution $\left(5 \times 10^{-5} \mathrm{M}\right)$ and Thin Film.

\begin{tabular}{|c|c|c|c|c|c|c|c|}
\cline { 2 - 7 } \multicolumn{1}{c|}{} & \multicolumn{3}{c|}{ Solution (room temperature) } & \multicolumn{2}{c|}{ Solution $(77 \mathrm{~K})$} & \multicolumn{2}{c|}{ Thin Film } \\
\hline Complex & $\lambda_{\mathrm{em}}(\mathrm{nm})^{a, b}$ & $\Phi_{\mathrm{PL}}(\%)^{a, b}$ & $\tau(\mathrm{ns})^{a, c}$ & $k_{\mathrm{r}} / 10^{5}\left(\mathrm{~s}^{-1}\right)^{d}$ & $k_{\mathrm{nr}} / 10^{5}\left(\mathrm{~s}^{-1}\right)$ & $\lambda_{\mathrm{em}}(\mathrm{nm})^{a, b}$ & $\lambda_{\mathrm{em}}(\%)^{e}$ \\
\hline
\end{tabular}




\begin{tabular}{|l|c|c|c|c|c|c|c|c|}
\hline$[\mathbf{1}]\left[\mathrm{PF}_{6}\right]$ & 516 & 20.4 & $316^{f}$ & 6.5 & 25.2 & 478,511 & 542 & 5.5 \\
\hline$[\mathbf{2}]\left[\mathrm{PF}_{6}\right]$ & 583 & 38.5 & 222 & 17.3 & 27.7 & 515,551 & 574 & 32.1 \\
\hline$[\mathbf{3}]\left[\mathrm{PF}_{6}\right]$ & 596 & 39.4 & 485 & 8.1 & 12.5 & 519,557 & 581 & 44.6 \\
\hline$[\mathbf{4}]\left[\mathrm{PF}_{6}\right]$ & 489,508 & 9.0 & 186 & 4.8 & 48.9 & 477,512 & 507 & 3.3 \\
\hline$[\mathbf{5}]\left[\mathrm{PF}_{6}\right]$ & 486,508 & 4.4 & 200 & 2.2 & 47.8 & 486,518 & $495(\mathrm{sh}) 514$ & 6.0 \\
\hline
\end{tabular}

${ }^{a}$ Deoxygenated acetonitrile solution. ${ }^{b} \lambda_{\mathrm{exc}}=360 \mathrm{~nm} .{ }^{c} \lambda_{\mathrm{exc}}=365 \mathrm{~nm} . k_{\mathrm{r}}=\Phi_{\mathrm{PL}} / \tau$ and $k_{\mathrm{r}}=\left(1-\Phi_{\mathrm{PL}}\right) / \tau .{ }^{e} \lambda_{\mathrm{exc}}=320 \mathrm{~nm} .{ }^{f}$ Average lifetime estimated using a biexponential fit (Table S4).

It is worth noting that, in contrast to the results observed in solution, where substitution of the $\mathrm{N}-\mathrm{H}$ group with a methyl has no systematic effect, the presence of the methyl group produces an increase of the quantum yield in thin film. The $\Phi_{\mathrm{PL}}$ augments from $32.1 \%$ in [2][ $\left.\mathrm{PF}_{6}\right]$ to $44.6 \%$ in [3] $\left[\mathrm{PF}_{6}\right]$, and from $3.3 \%$ in $[4]\left[\mathrm{PF}_{6}\right]$ to $6.0 \%$ in $[5]\left[\mathrm{PF}_{6}\right]$. The gain in $\Phi_{\mathrm{PL}}$ is attributed to the fact that, as discussed above, the methyl group prevents the aggregation of the complex in the solid state and reduces self-quenching processes.

\section{Theoretical calculations}

Density functional theory (DFT) and time-dependent DFT (TD-DFT) calculations were performed on the cations of complexes $[\mathbf{1}]\left[\mathrm{PF}_{6}\right]-[\mathbf{5}]\left[\mathrm{PF}_{6}\right]$ to get a better understanding of the electrochemical and photophysical properties discussed above. Calculations were carried out at the B3LYP/(6$31 \mathrm{G}^{* *+\mathrm{LANL}} \mathrm{DZ}$ ) level including solvent effects (see the Experimental Section for details).

Calculations predict a near-octahedral structure for cations $[\mathbf{1}]^{+}-[\mathbf{5}]^{+}$in their ground electronic state $\left(\mathrm{S}_{0}\right)$, in good agreement with the results observed for similar complexes in previous studies ${ }^{36,53,54,55,56}$ and the X-Ray structures reported above for complexes $[4]\left[\mathrm{PF}_{6}\right]$ and $[5]\left[\mathrm{PF}_{6}\right]$ (Figure 2). Both the cyclometalating and the ancillary ligands display coplanarity for their constituting rings, as it is usually found for iTMC complexes possessing five-atoms chelate rings and without bulky substituents in their molecular structure. ${ }^{32}$ The largest deviation from coplanarity is indeed found for the pyMebim $\mathrm{N}^{\wedge} \mathrm{N}$ ligand $\left(7.3^{\circ}\right)$ in $[3]\left[\mathrm{PF}_{6}\right]$ due to the methyl group introduced in the interannular region. The values predicted for the bite angles $\mathrm{C}-\mathrm{Ir}-\mathrm{N}\left(\sim 80.1^{\circ}\right)$ and $\mathrm{N}-\mathrm{Ir}-\mathrm{N}\left(\sim 74.5^{\circ}\right.$ for $[\mathbf{1}]^{+},[2]^{+}$, and $[4]^{+}$, and $\sim 74.0^{\circ}$ for $[3]^{+}$and $\left.[5]^{+}\right)$are very close to those obtained from the X-Ray structures of $[4]\left[\mathrm{PF}_{6}\right]$ and $[5]\left[\mathrm{PF}_{6}\right]$.

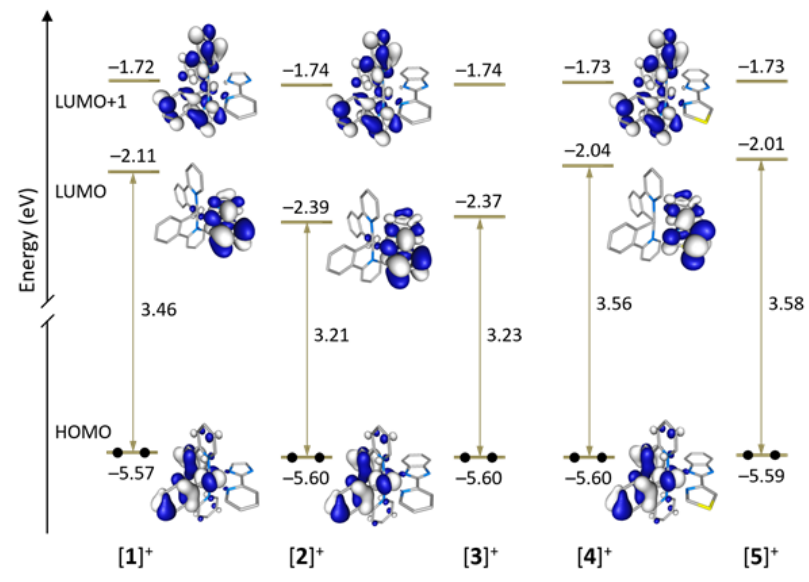

Figure 6. Energy diagram showing the isovalue contours $( \pm 0.03$ a.u.) and the energy values calculated for the HOMO, LUMO, and
LUMO +1 of complexes $[\mathbf{1}]^{+}$to $[\mathbf{5}]^{+}$. The MOs of $[\mathbf{3}]^{+}$and $[\mathbf{5}]^{+}$are identical to those of $[2]^{+}$and $[4]^{+}$and are not displayed.

Figure 6 displays the isovalue contours calculated for the highest-occupied (HOMO) and lowest-unoccupied molecular orbital (LUMO) of cations $[\mathbf{1}]^{+}-[\mathbf{5}]^{+}$. The LUMO+1 is also displayed because it plays a relevant role in the photophysical properties (see below). As it is usually found for ppy-based cyclometalated Ir-iTMCs, ${ }^{5,54,57}$ the HOMO of cations $[\mathbf{1}]^{+}-[\mathbf{5}]^{+}$ results from a mixture of $d_{\pi}$ orbitals of $\operatorname{Ir}(\mathrm{III})$ and phenyl $\pi$ orbitals, with some contribution from the pyridine rings of the cyclometalating ligands. As the five complexes share the same $\mathrm{C}^{\wedge} \mathrm{N}$ ligand, the HOMO has almost identical energies for all of them. This is in good agreement with the experimental $E^{\mathrm{ox}}{ }_{1 / 2}$ values (Table 1), which remain almost constant and imply the oxidation of the ppy-Ir environment. The same trend is found for the LUMO+1, which is centered on the cyclometalating ligands and presents almost the same energy for all the complexes (Figure 6).

In contrast to the HOMO, the LUMO is fully located over the ancillary $\mathrm{N}^{\wedge} \mathrm{N}$ ligand and its energy varies upon modifying the identity of the ligand. The condensation of a benzene ring to the imidazole ring to produce a benzimidazole unit leads to the stabilization of the LUMO by $\sim 0.3 \mathrm{eV}$ due to the extended conjugation. On the contrary, the exchange of the pyridine ring by a thiazole ring in $[4]^{+}$and $[5]^{+}$compensates the effect of benzene condensation and leads to a strong destabilization of the LUMO $(\sim 0,35 \mathrm{eV})$ compared to $[2]^{+}$and $[3]^{+}$. This destabilization is due to the strong electron-donating character of the thiazole ring resulting from the presence of the sulfur atom, which contributes with a lone electron pair to the aromatic $\pi$-system of the five-membered ring. Methylation of the imidazole ring has a very small effect, destabilizing the LUMO by around $0.02 \mathrm{eV}$. The changes predicted for the energy of the LUMO justify the less negative reduction potentials measured for $[2]\left[\mathrm{PF}_{6}\right](-1.95 \mathrm{~V})$ and $[3]\left[\mathrm{PF}_{6}\right](-1.91 \mathrm{~V})$ compared with $[1]\left[\mathrm{PF}_{6}\right](-2.20 \mathrm{~V})$, and the increase of the potential in passing to $[4]\left[\mathrm{PF}_{6}\right](-2.14 \mathrm{~V})$ and $[5]\left[\mathrm{PF}_{6}\right](-2.27$ $\mathrm{V})$. Upon reduction, the extra electron fully enters in the $\mathrm{N}^{\wedge} \mathrm{N}$ ligand as illustrated by the unpaired-electron spin densities shown in Figure S7 for the radical species [3] $]^{\circ}$ and [5]". It is to be noted that for [5] a high spin density of $0.47 \mathrm{e}$ is located on the $\mathrm{C} 2$ atom of the thiazole ring (see Figure 2 for atom numbering). The highly localized nature of the unpaired electron could explain the instability of the reduced species of $[5]\left[\mathrm{PF}_{6}\right]$ despite the $\mathrm{N}-\mathrm{H}$ group of the pybim unit is protected with a methyl group as in [3][ $\left.\mathrm{PF}_{6}\right]$.

The size of the HOMO-LUMO energy gap is therefore mainly determined by the position of the LUMO and increases along the series $[\mathbf{2}]^{+} \approx[\mathbf{3}]^{+}<[\mathbf{1}]^{+}<[\mathbf{4}]^{+} \approx[\mathbf{5}]^{+}$. Obviously, if a direct correlation is established between the HOMO-LUMO gap and the emission energy, bluer emissions have to be expected along this series, which is indeed in agreement with the experimental trend observed for the emission maxima (Table 2). 
However, the picture is not as simple since, as discussed in the previous section, experimental evidences point to a different electronic nature of the emitting triplet state. Therefore, we cannot directly presume that emission originates from the HOMO $\rightarrow$ LUMO transition for all the complexes. TD-DFT calculations will help us to elucidate the nature of the emitting state and to rationalize the experimental observations.

TD-DFT calculations were performed for the lowest-energy triplet $\left(\mathrm{T}_{n}\right)$ excited states of cations $[\mathbf{1}]^{+}$to $[\mathbf{5}]^{+}$. The results obtained for the four lowest triplets (vertical excitation energies, description in terms of orbital monoexcitations, and electronic nature) are detailed in Table S5 in the Supporting Information and are summarized in a graphical way in Figure 7. For each cation, two triplet states of LC nature with some MLCT character are found, which are mainly described by the $\mathrm{HOMO} \rightarrow \mathrm{LUMO}+1$ and $\mathrm{HOMO} \rightarrow \mathrm{LUMO}+2$ excitations. As all these orbitals are located on the $\mathrm{C}^{\wedge} \mathrm{N}$ ligands with some participation of the metal (Figure 6), they remain unchanged along the series and the resulting ${ }^{3} \mathrm{LC}\left(\mathrm{C}^{\wedge} \mathrm{N}\right)$ states present almost the same energy ( 2.75 and $2.79 \mathrm{eV})$ for all the complexes (Figure 7). The HOMO $\rightarrow$ LUMO excitation implies an electron transfer from the ppy-Ir environment, where the $\mathrm{HOMO}$ is located, to the $\mathrm{N}^{\wedge} \mathrm{N}$ ligand, where the LUMO resides (Figure 6), and therefore gives rise to a triplet state of mixed ${ }^{3} \mathrm{MLCT} /{ }^{3} \mathrm{LLCT}$ character. The state is calculated as the lowest triplet at $2.73 \mathrm{eV}$ for $[\mathbf{1}]^{+}$, very close in energy to the ${ }^{3} \mathrm{LC}\left(\mathrm{C}^{\wedge} \mathrm{N}\right)$ states, and stabilizes to $2.51 \mathrm{eV}$ for $[2]^{+}$and $[3]^{+}$ (Figure 7), accordingly with the stabilization of the LUMO when pybim is used as ancillary ligand. For $[4]^{+}$and $[5]^{+}$, the ${ }^{3} \mathrm{MLCT} /{ }^{3} \mathrm{LLCT}$ state increases in energy to 2.95 and $2.97 \mathrm{eV}$, respectively, because of the LUMO destabilization induced by the replacement of the pyridyl ring with the thiazole ring, and it is by no longer the lowest triplet. It appears as $\mathrm{T}_{4}$ (Figure 7). A fourth state of mixed ${ }^{3} \mathrm{LC}\left(\mathrm{N}^{\wedge} \mathrm{N}\right) /{ }^{3} \mathrm{MLCT} /{ }^{3} \mathrm{LLCT}$ character mainly resulting from the HOMO- $\rightarrow$ LUMO or HOMO- $2 \rightarrow$ LUMO excitations is also computed within the low energy triplets.

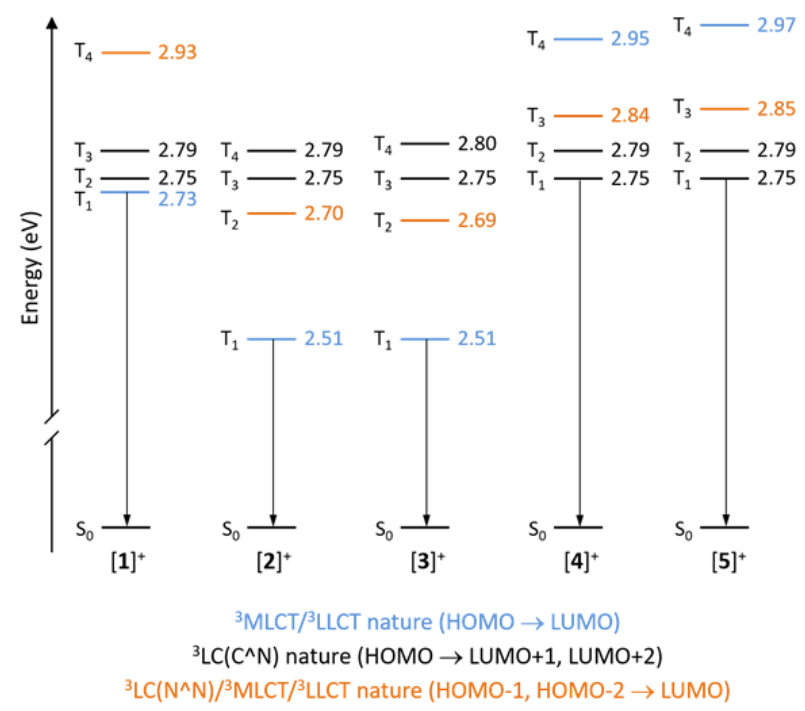

Figure 7. Energy diagram showing the energy values calculated for the lowest-energy triplet excited states $\left(\mathrm{T}_{n}\right)$ of complexes $[\mathbf{1}]^{+}$ to $[5]^{+}$. The different electronic nature of the $\mathrm{T}_{n}$ states is denoted by using different colors.
The electronic nature of the lowest-lying $\mathrm{T}_{1}$ triplet therefore changes along the series $[\mathbf{1}]^{+}$to $[\mathbf{5}]^{+}$(Figure 7 ). For $[\mathbf{2}]^{+}$and $[3]^{+}$, the HOMO $\rightarrow$ LUMO ${ }^{3} \mathrm{MLCT}{ }^{3}$ LLCT state is lower in energy than the ${ }^{3} \mathrm{LC}\left(\mathrm{C}^{\wedge} \mathrm{N}\right)$ states and it clearly corresponds to the emitting state. This assignment supports the $\mathrm{CT}$ character proposed for this state in $[2]\left[\mathrm{PF}_{6}\right]$ and $[3]\left[\mathrm{PF}_{6}\right]$ on the basis of the broad and unstructured emission bands observed experimentally (Figure 5a). For $[4]^{+}$and $[5]^{+}$, the destabilization of the ${ }^{3} \mathrm{MLCT} /{ }^{3} \mathrm{LLCT}$ state makes the ${ }^{3} \mathrm{LC}\left(\mathrm{C}^{\wedge} \mathrm{N}\right)$ triplets the lowest-lying states. The LC character of the emitting state explains the different photophysical behavior observed for complexes $[4]\left[\mathrm{PF}_{6}\right]$ and $[5]\left[\mathrm{PF}_{6}\right]$, which present structured emission bands with no significant rigidochromic shift at low temperatures (Figure 5a and b). For $\left[\mathbf{1}^{+}\right.$, TD-DFT calculations predict that the ${ }^{3} \mathrm{MLCT} /{ }^{3} \mathrm{LLCT}$ state and the ${ }^{3} \mathrm{LC}\left(\mathrm{C}^{\wedge} \mathrm{N}\right)$ triplets are very close in energy and they can compete as emitting states. Experimental evidences actually point in this direction since the emission spectrum of $[1]\left[\mathrm{PF}_{6}\right]$ shows a nearly unnoticeable vibrational structure, and looks intermediate between those of $[2]\left[\mathrm{PF}_{6}\right]$ and $[3]\left[\mathrm{PF}_{6}\right]$ and those of $[4]\left[\mathrm{PF}_{6}\right]$ and $[5]\left[\mathrm{PF}_{6}\right]$ (Figure 5).
$[1]^{+}$

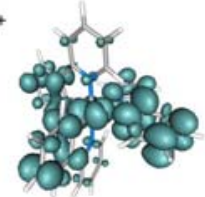

$\mathrm{T}_{1}\left({ }^{3} \mathrm{MLCT} /{ }^{3} \mathrm{LLCT}\right)$

$[2]^{+}$

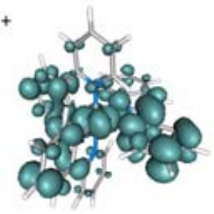

$\mathrm{T}_{1}\left({ }^{3} \mathrm{MLCT} /{ }^{3} \mathrm{LLCT}\right)$
$[1]^{+}$

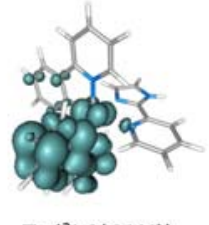

$[4]^{+}$

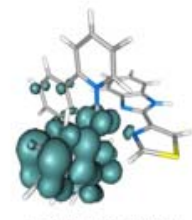

$\mathrm{T}_{1}\left({ }^{3} \mathrm{LC}\left(\mathrm{C}^{\wedge} \mathrm{N}\right)\right)$
Figure 8. Unpaired-electron spin-density contours (0.002 a.u.) calculated for fully relaxed $T_{1}$ and $T_{2}$ states of $[1]^{+}$and $T_{1}$ states of $[2]^{+}$and $[4]^{+}$. The nature of the states is indicated within parentheses.

To get additional information about the emitting state, the geometries of the lowest triplet state of $[\mathbf{1}]^{+}-[\mathbf{5}]^{+}$were optimized using the spin-unrestricted UB3LYP approach. For $[\mathbf{1}]^{+}$, both the $\mathrm{T}_{1}\left({ }^{3} \mathrm{MLCT} /{ }^{3} \mathrm{LLCT}\right)$ and $\mathrm{T}_{2}\left({ }^{3} \mathrm{LC}\left(\mathrm{C}^{\wedge} \mathrm{N}\right)\right)$ triplets were calculated at the UB3LYP level. Figure 8 displays the unpaired-electron spin density distributions calculated for $[\mathbf{1}]^{+}$ $\left(\mathrm{T}_{1}\right.$ and $\left.\mathrm{T}_{2}\right),[2]^{+}$, and $[4]^{+}$at their optimized geometries. Those computed for $[\mathbf{3}]^{+}$and $[\mathbf{5}]^{+}$are identical to those shown for $[\mathbf{2}]^{+}$ and $[4]^{+}$, respectively (Figure S8). For $[2]^{+}$and $[3]^{+}, \mathrm{T}_{1}$ features a spin density distribution spreading the ppy-Ir environment and the ligand ( $\operatorname{Ir} 0.55 \mathrm{e}, \mathrm{C}^{\wedge} \mathrm{N}$ ligands $0.43 \mathrm{e}, \mathrm{N}^{\wedge} \mathrm{N}$ ligand $1.02 \mathrm{e})$ that perfectly matches the topology of the HOMO $\rightarrow$ LUMO MLCT/LLCT excitation. In contrast, for $[\mathbf{4}]^{+}$and $[5]^{+}$ the spin-density distribution is mainly centered on one of the cyclometalating ligands ( 1.7 unpaired electrons $)$ with a small contribution from the metal $(\sim 0.3 \mathrm{e})$. UB3LYP calculations therefore confirm the ${ }^{3} \mathrm{MLCT} /{ }^{3} \mathrm{LLCT}$ character of the emitting triplet for $[2]^{+}$and $[3]^{+}$and the predominant ${ }^{3} \mathrm{LC}$ nature of that triplet for $[4]^{+}$and $[\mathbf{5}]^{+}$. For $[\mathbf{1}]^{+}$, the $T_{1}$ and $T_{2}$ states remain mostly isoenergetic after relaxation $(\Delta E=2.59$ and $2.61 \mathrm{eV}$, 
respectively, calculated as the difference between the total energies of $S_{0}$ and $T_{1} / T_{2}$ at their respective minimum energy structures), the ${ }^{3} \mathrm{MLCT} /{ }^{\beta} \mathrm{LLCT}$ state being slightly more stable. Thus, emission could take place both from $\mathrm{T}_{1}$ or $\mathrm{T}_{2}$.

The calculated emission energies, estimated as the vertical energy difference between $T_{1}$ and $S_{0}$ at the optimized minimum-energy geometry of $T_{1}$, follow closely the experimental values of the emission maxima. The values predicted for $[2]^{+}$ $(590 \mathrm{~nm})$ and $[3]^{+}(593 \mathrm{~nm})$ are in good accordance with the experimental values (583 and $596 \mathrm{~nm}$, respectively), whereas those obtained for [1] $]^{+}(534 \mathrm{~nm}),[4]^{+}(527 \mathrm{~nm})$, and [5] ${ }^{+}(528$ $\mathrm{nm}$ ) slightly overestimate the experimental values (516, $489-508,486-508 \mathrm{~nm}$, respectively).

\section{Light-emitting electrochemical devices}

Light-emitting electrochemical cells (LECs) were fabricated with complexes $[\mathbf{1}]\left[\mathrm{PF}_{6}\right]-[\mathbf{5}]\left[\mathrm{PF}_{6}\right]$ in a double layer architecture consisting of a poly $(3,4-$ ethylenedioxythiophene):poly(styrenesulfonate)

(PEDOT:PSS) layer and the emissive layer sandwiched between indium tin oxide (ITO) and aluminum electrodes. The active layer contained the Ir-iTMC mixed with the ionic liquid (IL) 1-butyl-3-methylimidazolium hexafluorophosphate [Bmim] $\left[\mathrm{PF}_{6}\right]$ at a 4:1 (iTMC:IL) molar ratio. The IL was added to shorten the turn-on time of the LEC by increasing the concentration of ionic species and the ionic mobility in the light-emitting layer. ${ }^{26,58}$ After deposition of the emissive layer, the devices were transferred to an inert atmosphere glove box $\left(<0.1\right.$ ppm $\mathrm{O}_{2}$ and $\left.\mathrm{H}_{2} \mathrm{O}\right)$. The time-dependence of the luminance and average voltage of the LECs prepared was evaluated using a pulsed-current driving mode. LECs were operated by applying a block-wave pulsed current (frequency: $1 \mathrm{kHz}$, duty cycle: $50 \%$ ), where the peak current density of the pulse was $200 \mathrm{~A} \cdot \mathrm{m}^{-2}$ and the average current density was 100 $\mathrm{A} \cdot \mathrm{m}^{-2}$. Pulsed-current driving has been demonstrated to lead to devices with longer lifetimes and faster response compared to fixed-current/voltage driving. ${ }^{23}$

The dependence of the luminance and average voltage with time is depicted in Figure 9 and key parameters derived from the graphs are collected in Table 3. All the devices present a fast initial decrease of the voltage until a minimum stable value $(2.3-2.7 \mathrm{~V})$ is reached. This behavior is typical under the pulsed-current driving applied due to the operation mechanism of LECs. The voltage required to maintain the current density decreases versus time due to the formation of $\mathrm{p}$ - and $\mathrm{n}$ doped regions, which reduces the resistance of the active layer. The fact that the voltage remains in all cases close to the minimum along the device operation time reveals that there are no signs of charge transport issues or chemical degradation. Except for device with $[4]\left[\mathrm{PF}_{6}\right]$, that does not emit any light, the luminance increases until a maximum is reached and then starts to decrease. The parameters used to quantify the response of the device are the time to reach this maximum luminance $\left(t_{\max }\right)$ and the time to reach a luminance value of $100 \mathrm{~cd} \mathrm{~m}^{-2}\left(t_{\mathrm{on}}\right)$. The $t_{\mathrm{on}}$ for devices with [1] $\left[\mathrm{PF}_{6}\right]$ and $[\mathbf{5}]\left[\mathrm{PF}_{6}\right]$ was not established because these LECs did not achieve the threshold of $100 \mathrm{~cd} \mathrm{~m}^{-2}$, yet they started up very rapidly and reached luminance levels of 18 and $51 \mathrm{~cd} \cdot \mathrm{m}^{-2}$ within $4 \mathrm{~s}$, respectively.

(a)
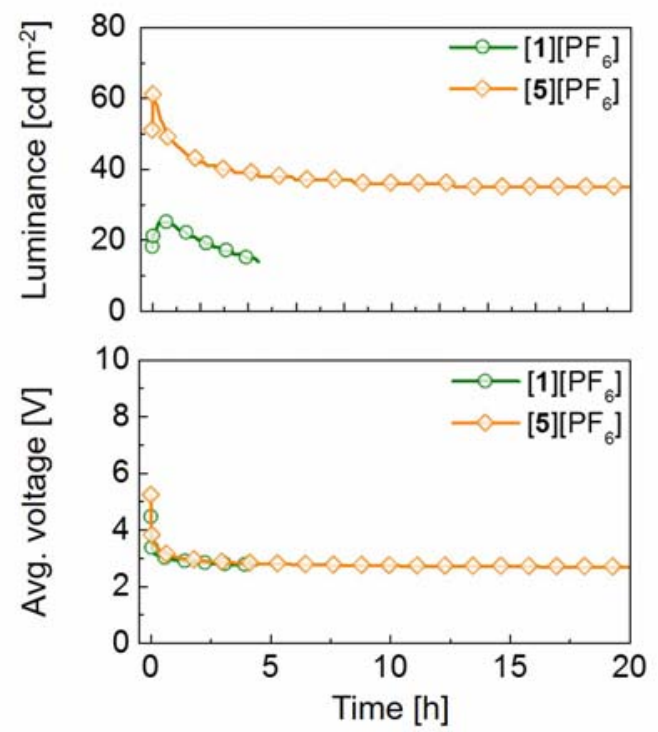

(b)
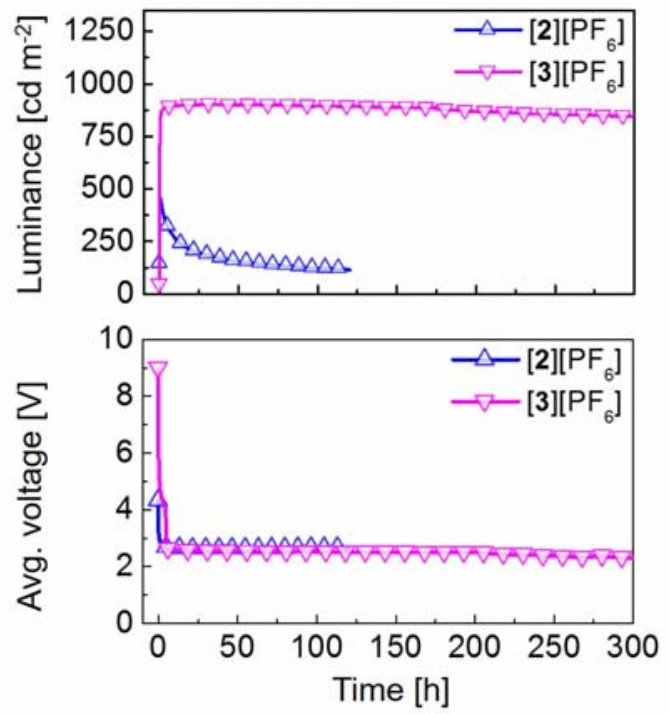

Figure 9. Luminance and average voltage for ITO/PEDOT:PSS/iTMC:[Bmim][PF 6 (4:1 molar ratio)/Al LEC devices measured by applying a block-wave pulsed current of 100 $\mathrm{A} \mathrm{m}^{-2}$ at a frequency of $1 \mathrm{kHz}$ and duty cycles of $50 \%$. a) $\mathrm{iTMC}=$ $[1]\left[\mathrm{PF}_{6}\right]$ and $[5]\left[\mathrm{PF}_{6}\right] ;$ b) iTMC $=[2]\left[\mathrm{PF}_{6}\right]$ and $[3]\left[\mathrm{PF}_{6}\right]$.

Table 3. Performance Parameters Obtained for ITO/PEDOT:PSS/Active Layer/Al LEC Devices Measured by Applying a Block-Wave Pulsed Current of $100 \mathrm{~A} \mathrm{~m}^{-2}$ at a Frequency of $1 \mathrm{kHz}$ and Duty Cycles of 50\%. Active Layer: [1][PF $\left.{ }_{6}\right],[2]\left[\mathrm{PF}_{6}\right]$, $[3]\left[\mathrm{PF}_{6}\right]$, and $[5]\left[\mathrm{PF}_{6}\right]:[\mathrm{Bmim}]\left[\mathrm{PF}_{6}\right]$ at a $4: 1$ Molar Ratio.

\begin{tabular}{|c|c|c|c|c|c|c|c|c|}
\hline Complex & $\begin{array}{c}\operatorname{Lum}_{\mathrm{o}}{ }^{a} \\
\left(\mathrm{~cd} \cdot \mathrm{m}^{-2}\right)\end{array}$ & $\begin{array}{c}\operatorname{Lum}_{\max }{ }^{b} \\
\left(\mathrm{~cd} \cdot \mathrm{m}^{-2}\right)\end{array}$ & $\begin{array}{c}t_{\mathrm{on}}{ }^{c} \\
(\mathrm{~s})\end{array}$ & $\begin{array}{c}t_{\max }{ }^{d} \\
(\mathrm{~min})\end{array}$ & $\begin{array}{c}t_{1 / 2}{ }^{e} \\
(\mathrm{~h})\end{array}$ & $\begin{array}{c}\text { Efficacy }^{f} \\
\left(\mathrm{~cd} \cdot \mathrm{A}^{-1}\right)\end{array}$ & $\begin{array}{c}\mathrm{EQE}^{g} \\
(\%)\end{array}$ & $\begin{array}{c}\mathrm{PCE}^{h} \\
\left(\mathrm{~lm} \cdot \mathrm{W}^{-1}\right)\end{array}$ \\
\hline
\end{tabular}




\begin{tabular}{|c|c|c|c|c|c|c|c|c|}
\hline$[\mathbf{1}]\left[\mathrm{PF}_{6}\right]$ & 18 & 25 & - & 15 & 2.25 & 0.3 & 0.1 & 1.3 \\
\hline$[2]\left[\mathrm{PF}_{6}\right]$ & 143 & 460 & $<4$ & 18 & 0.30 & 4.6 & 1.4 & 2.5 \\
\hline$[3]\left[\mathrm{PF}_{6}\right]$ & 44 & 904 & 6.9 & 1680 & $2700 *$ & 9.2 & 3.0 & 5.7 \\
\hline$[5]\left[\mathrm{PF}_{6}\right]$ & 51 & 61 & - & 1 & 200 & 0.6 & 0.2 & 0.3 \\
\hline
\end{tabular}

${ }^{a}$ Initial luminance. ${ }^{b}$ Maximum luminance reached. ${ }^{c}$ Time to reach $100 \mathrm{~cd} \cdot \mathrm{m}^{-2}$ luminance. ${ }^{d}$ Time to reach the maximum luminance. ${ }^{e}$ Time to reach one-half of the maximum luminance after $t_{\max }$ is attained. ${ }^{f}$ Maximum efficacy (ratio luminance/average current). ${ }^{g}$ Maximum external quantum efficiency reached. ${ }^{h}$ Maximum power conversion efficiency reached. *Extrapolated value.

The absence of light emission for $[4]\left[\mathrm{PF}_{6}\right]$ and the low luminance observed for $[\mathbf{1}]\left[\mathrm{PF}_{6}\right]$ and $[\mathbf{5}]\left[\mathrm{PF}_{6}\right]$ can be related with

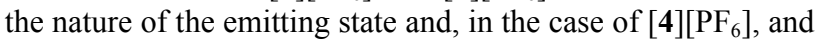
probably $[1]\left[\mathrm{PF}_{6}\right]$ as well, with the observed formation of dimeric entities in the crystal that favor self-quenching processes. As discussed above, the emitting state of these complexes has a predominant ${ }^{3} \mathrm{LC}$ character with small participation of the iridium center. This limits the intersystem crossing and, as a consequence, low $\Phi_{\mathrm{PL}}$ values are obtained for $[1]\left[\mathrm{PF}_{6}\right](5.5 \%),[4]\left[\mathrm{PF}_{6}\right](3.3 \%)$, and $[5]\left[\mathrm{PF}_{6}\right](6.0 \%)$ in thin film (Table 2). In contrast, $[2]\left[\mathrm{PF}_{6}\right]$ and $[3]\left[\mathrm{PF}_{6}\right]$ have emitting states of ${ }^{3} \mathrm{MLCT} /{ }^{3} \mathrm{LLCT}$ nature with higher $\Phi_{\mathrm{PL}}$ values $(32.1$ and $44.6 \%$, respectively), and their LECs feature much higher luminances $\left(\mathrm{Lum}_{\max }=460\right.$ and $906 \mathrm{~cd} \mathrm{~m}^{-2}$, respectively), comparable to those of the devices with the highest luminance maxima available in the literature for this wavelength range. ${ }^{24,11}$ The higher luminance registered for the $[3]\left[\mathrm{PF}_{6}\right]$ device combines with a top efficiency (efficacy of $9.2 \mathrm{~cd} \mathrm{~A}^{-1}$ and external quantum efficiency of $3.0 \%$ ), and is in good agreement with the higher $\Phi_{\mathrm{PL}}$ recorded for this complex in thin film. In addition, the LECs with $[2]\left[\mathrm{PF}_{6}\right]$ and $[3]\left[\mathrm{PF}_{6}\right]$ show a fast response, the longest $t_{\mathrm{on}}(7 \mathrm{~s})$ being found for the LEC with $[3]\left[\mathrm{PF}_{6}\right]$.

The stability of the devices was estimated as the decay time required for reaching one-half of the maximum luminance $\left(t_{1 / 2}\right)$ after the $t_{\max }$ is attained. The values obtained for $t_{1 / 2}$ (Table 3 ) indicate that the condensation of a benzene to the imidazole ring, which leads to increased luminescence, does not improve the device lifetime. In fact, the device made with the pybim-containing complex $[2]\left[\mathrm{PF}_{6}\right]$ features a short $t_{1 / 2}$ of only $0.30 \mathrm{~h}$, shorter than that of the pyim-containing $[1]\left[\mathrm{PF}_{6}\right]$ device $(2.25 \mathrm{~h})$. These low device stabilities are in line with the instability of the reduced species observed electrochemically, which is attributed to the high reactivity of the $\mathrm{N}-\mathrm{H}$ bond. The presence of this bond therefore is likely to be the origin of the limited device stability of $[1]\left[\mathrm{PF}_{6}\right],[2]\left[\mathrm{PF}_{6}\right]$, and also $[4]\left[\mathrm{PF}_{6}\right]$ which emits no light. However, when the imidazole $\mathrm{N}-\mathrm{H}$ bond is substituted with a methyl group, the LEC stability improves dramatically, and $t_{1 / 2}$ increases up to $200 \mathrm{~h}$ in $[5]\left[\mathrm{PF}_{6}\right]$ and above $2500 \mathrm{~h}$ in $[3]\left[\mathrm{PF}_{6}\right]$. The luminance of the $[3]\left[\mathrm{PF}_{6}\right]$ device decreases only by $12 \%$ after $650 \mathrm{~h}$ ( 27 days) of continuous operation, and the linear extrapolation of the time dependence of luminance provides the value of $t_{1 / 2}=2700 \mathrm{~h}$, which is a remarkable result for a LEC (Figure 9). The value of $t_{1 / 2}$ extrapolated for $[3]\left[\mathrm{PF}_{6}\right]$ is among the best values available in the bibliography for LECs. In a recent review, ${ }^{11}$ Henwood and Zysman-Colman concluded that the most stable emitter reported to date under the same pulsed current operation of 100 $\mathrm{A} \mathrm{m}^{-2}$ was presented by Tordera et al., ${ }^{59}$ who described a LEC device based on an imidazole-including complex $([\operatorname{Ir}(\mathrm{ppy}) 2(\mathrm{imp})] \quad(\mathrm{imp}=1 \mathrm{H}$-imidazo[4,5f] $[1,10]$ phenantroline)) that featured high lifetime and luminescence and low turn-on times. The results obtained here for the device manufactured with complex $[3]\left[\mathrm{PF}_{6}\right]$ are even better than those of the device with $[\operatorname{Ir}(\mathrm{ppy}) 2(\mathrm{imp})]\left[\mathrm{PF}_{6}\right]$. The device stability obtained when using $[3]\left[\mathrm{PF}_{6}\right]$ is longer $\left(t_{1 / 2}=2700 \mathrm{vs}\right.$. $2000 \mathrm{~h}$ ), the turn-on time is shorter (6.9 vs. $45 \mathrm{~s})$, the maximum luminance is higher ( $904 \mathrm{vs} .684 \mathrm{~cd} \mathrm{~m}^{-2}$ ), and the maximum current efficiency is also higher $\left(9.2 \mathrm{vs} 6.5 \mathrm{~cd} \mathrm{~A}^{-1}\right)$. The values obtained here are also in excess of the most stable yellow-orange emitting LEC $\left(t_{1 / 2} \approx 4000 \mathrm{~h}, 3.6 \mathrm{~cd} \mathrm{~A}^{-1}\right)$, that was operated under different pulsed current conditions $(30 \%$ of duty cycle). ${ }^{23}$ They are also competitive with the top peak efficiencies $\left(18.6 \mathrm{~cd} \mathrm{~A}^{-1}\right)$ obtained by He et al. under constant voltage operation that leads to higher peak luminances and higher currents accompanied by a strong reduction in lifetime. ${ }^{38}$ Interestingly, the exceptional efficiency found for the [3] $\left[\mathrm{PF}_{6}\right]$ LEC $\left(9.2 \mathrm{~cd} \mathrm{~A}^{-1}\right)$ is much higher than the efficiency previously obtained for this complex under voltage scan $(1.5$ $\left.\mathrm{cd} \mathrm{A}^{-1}\right){ }^{40}$

Figure 10 shows the electroluminescence (EL) spectra of the four LECs and Table 4 summarizes the key parameters obtained from the EL spectra. The position of the emission maxima is similar to that recorded in the thin-film photoluminescence spectra for $[\mathbf{1}]\left[\mathrm{PF}_{6}\right],[2]\left[\mathrm{PF}_{6}\right]$, and $[3]\left[\mathrm{PF}_{6}\right]$ (Table 2 and 4). However, the emission is red-shifted by $47 \mathrm{~nm}$ in the device of complex [5][ $\left.\mathrm{PF}_{6}\right]$, which presents a shoulder at $493 \mathrm{~nm}$ that was also observed in the PL spectrum in thin film (Table 2). The shift of the emission could be due to the electric field present in the device that stabilizes the ${ }^{3} \mathrm{LC}$ emitting state of the complex, whereas the shoulder would correspond to the emission from a close triplet state (Table S5) not affected by the electric field. LEC devices emit green light for $[1]\left[\mathrm{PF}_{6}\right]$ and $[5]\left[\mathrm{PF}_{6}\right]$ and yellow light for $[2]\left[\mathrm{PF}_{6}\right]$ and $[3]\left[\mathrm{PF}_{6}\right]$.

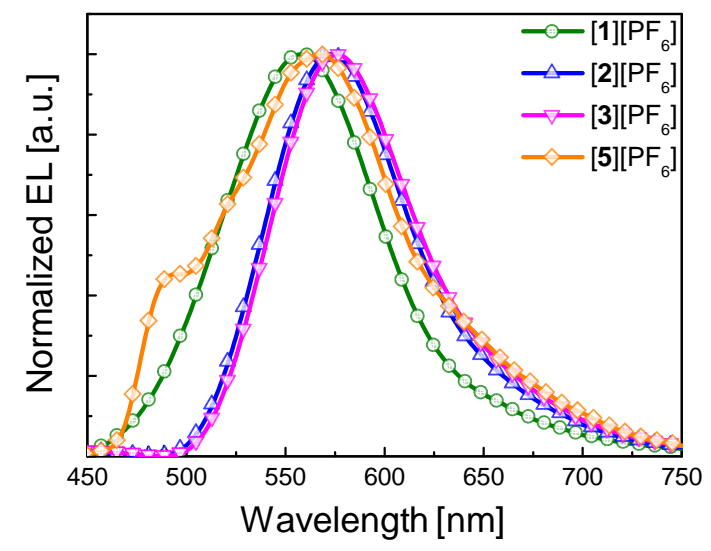

Figure 10. Normalized electroluminescence (EL) spectra of LECs based on complexes $[\mathbf{1}]\left[\mathrm{PF}_{6}\right],[\mathbf{2}]\left[\mathrm{PF}_{6}\right],[3]\left[\mathrm{PF}_{6}\right]$, and $[\mathbf{5}]\left[\mathrm{PF}_{6}\right]$. 
Table 4. Electroluminescence Parameters of LECs under Block-Wave Pulsed Current of $100 \mathrm{~A} \mathrm{~m}^{-2}$ at a Frequency of $1 \mathrm{kHz}$ and Duty Cycles of $50 \%$.

\begin{tabular}{|c|c|c|}
\hline Complex & $\lambda_{\text {max,EL, }}(\mathrm{nm})$ & CIE coordinates \\
\hline$[\mathbf{1}]\left[\mathrm{PF}_{6}\right]$ & 558 & $(0.4008,0.5570)$ \\
\hline$[2]\left[\mathrm{PF}_{6}\right]$ & 573 & $(0.4811,0.5109)$ \\
\hline$[3]\left[\mathrm{PF}_{6}\right]$ & 576 & $(0.4933,0.5007)$ \\
\hline$[\mathbf{5}]\left[\mathrm{PF}_{6}\right]$ & $567(493 \mathrm{sh})$ & $(0.4138,0.5219)$ \\
\hline
\end{tabular}

\section{CONCLUSIONS}

A series of $\left[\operatorname{Ir}(\mathrm{ppy})_{2}\left(\mathrm{~N}^{\wedge} \mathrm{N}\right)\right]\left[\mathrm{PF}_{6}\right]$ complexes with 2phenylpyridinate cyclometalating ligands and different $\mathrm{N}^{\wedge} \mathrm{N}$ arylazole ancillary ligands has been prepared and fully characterized. X-ray structural data are reported for complexes $[4]\left[\mathrm{PF}_{6}\right]$ and $[5]\left[\mathrm{PF}_{6}\right]$ incorporating thiazolyl rings.

The complexes show significantly different photoluminescence properties in solution depending on the chemical structure of the ancillary ligand. Complexes $[2]\left[\mathrm{PF}_{6}\right]$ and $[3]\left[\mathrm{PF}_{6}\right]$, bearing 2-(2-pyridyl)benzimidazole (pybim) and 1-methyl-2pyridin-2-yl-1H-benzimidazole (pyMebim) $\mathrm{N}^{\wedge} \mathrm{N}$ ligands, respectively, exhibit broad unstructured emission bands with maxima around $590 \mathrm{~nm}$ and experience a notable rigidochromic effect when recorded at $77 \mathrm{~K}$. In contrast, complexes $[4]\left[\mathrm{PF}_{6}\right]$ and $[5]\left[\mathrm{PF}_{6}\right]$, in which the pyridyl ring of the $\mathrm{N}^{\wedge} \mathrm{N}$ ligand is substituted by a thiazolyl ring, present vibrationally-structured emission bands peaking around $500 \mathrm{~nm}$ with no significant rigidochromic shift. DFT calculations fully justify the different photophysical behavior. The presence of the benzimidazole unit in $[2]\left[\mathrm{PF}_{6}\right]$ and $[3]\left[\mathrm{PF}_{6}\right]$ strongly stabilizes the LUMO (located on the ancillary ligand) and determines a ${ }^{3} \mathrm{MLCT} /{ }^{3} \mathrm{LLCT}$ character for the lowest-energy emitting triplet state. In contrast, the incorporation of the thiazolyl ring destabilizes the LUMO and thereby the HOMO $\rightarrow$ LUMO ${ }^{3} \mathrm{MLCT} /{ }^{3} \mathrm{LLCT}$ state in $[4]\left[\mathrm{PF}_{6}\right]$ and $[5]\left[\mathrm{PF}_{6}\right]$, and the emitting triplet has a predominant ${ }^{3} \mathrm{LC}$ nature. The different nature of $\mathrm{T}_{1}$ explains the low PLQYs $(<10 \%)$ measured for $[4]\left[\mathrm{PF}_{6}\right]$ and $[5]\left[\mathrm{PF}_{6}\right]$. Complex $[1]\left[\mathrm{PF}_{6}\right]$, bearing a $2-(1 \mathrm{H}-$ imidazol-2-yl)pyridine $\mathrm{N}^{\wedge} \mathrm{N}$ ligand, displays an intermediate behavior due to close energy of the ${ }^{3} \mathrm{MLCT} /{ }^{3} \mathrm{LLCT}$ and ${ }^{3} \mathrm{LC}$ states.

Light-emitting electrochemical cells prepared with complexes $[\mathbf{1}]\left[\mathrm{PF}_{6}\right]-[5]\left[\mathrm{PF}_{6}\right]$ also present very different performances, in line with the photophysical and electronic structure differences mentioned above. LECs prepared with $[2]\left[\mathrm{PF}_{6}\right]$ and $[3]\left[\mathrm{PF}_{6}\right]$ $\left({ }^{3} \mathrm{MLCT} /{ }^{3} \mathrm{LLCT}\right.$ emissive state) feature yellow color, high luminances (460 and $904 \mathrm{~cd} \mathrm{~m}^{-2}$ ) and efficiencies (4.61 and $9.15 \mathrm{~cd} \mathrm{~A}^{-1}$ ), and low turn-on times (a few seconds). In contrast, LECs prepared with complexes $[\mathbf{1}]\left[\mathrm{PF}_{6}\right]$ and $[5]\left[\mathrm{PF}_{6}\right]$, for which the emissive state has an important ${ }^{3} \mathrm{LC}$ character, exhibit green color and low luminances (25 and $61 \mathrm{~cd} \mathrm{~m}^{-2}$ ). LECs with complexes bearing unprotected imidazole $\mathrm{N}-\mathrm{H}$ bonds show short lifetimes $\left([\mathbf{1}]\left[\mathrm{PF}_{6}\right]\right.$ and $\left.[2]\left[\mathrm{PF}_{6}\right]\right)$ or emit no light $\left([4]\left[\mathrm{PF}_{6}\right]\right)$. The LEC based on $[3]\left[\mathrm{PF}_{6}\right]$ exhibits record performance, simultaneously presenting high luminance and efficiency, short turn-on time, and high stability reaching lifetimes over 2500 hours.

The use of the benzimidazole unit in the ancillary ligand without incorporating bulky groups is therefore confirmed as an efficient strategy to obtain LECs with long lifetimes, short turn on times, and high luminances, provided that the $\mathrm{N}-\mathrm{H}$ group of the imidazole ring is conveniently protected with a methyl substitution.

\section{ACKNOWLEDGEMENTS}

Financial support by the Spanish Ministry of Economy and Competitiveness (MINECO) of Spain (projects CTQ2014-58812-C21-R, MAT2014-55200， CTQ2014-55583-R， CTQ2014-61914EXP, CTQ2015-71955-REDT, CTQ2015-71154-P, and Unidad de Excelencia María de Maeztu MDM-2015-0538), European Feder funds (CTQ2015-71154-P), Obra Social "la Caixa" (OSLC2012-007), Junta de Castilla y León (BU033-U16), and Generalitat Valenciana (Prometeo2016/135) is gratefully acknowledged. We are also indebted to A. Colina for his inspiring comments and generosity, and to P. Castroviejo and M. Mansilla, from PCI of the University of Burgos, for technical support. C.M. thanks the MINECO for a predoctoral grant.

\section{EXPERIMENTAL SECTION}

\section{General Methods and starting materials.}

Starting materials. $\mathrm{IrCl}_{3} \cdot x \mathrm{H}_{2} \mathrm{O}$ was purchased from Johnson Mattey and used as received. $\left[\operatorname{Ir}(\mu-\mathrm{Cl})(\mathrm{ppy})_{2}\right]_{2}$ (Hppy $=$ phenylpyridine) was prepared according to literature procedures. ${ }^{45,60,61}$ The salts AgOTs, $\left[\mathrm{NH}_{4}\right]\left[\mathrm{PF}_{6}\right]$, and $\mathrm{NaBPh}_{4}$ and the ligands 2-(2-pyridyl)benzimidazole (pybim) and 2-(4'thiazolyl)benzimidazole (thiabendazole, tbz) were purchased from Sigma-Aldrich and used without further purification. The ligands 2-(1H-imidazol-2-yl)pyridine (pyim), ${ }^{62,63}$ 1-methyl-2pyridin-2-yl-1H-benzimidazole (pyMebim), ${ }^{64}$ and 1-methyl-2(4'-thiazolyl)benzimidazole (Metbz) were prepared according to literature procedures or via adapted literature protocols. Deuterated solvents were obtained from $\mathrm{SDS}\left(\mathrm{CD}_{3} \mathrm{SOCD}_{3}\right)$ and Carlo Erba or Euriso-top $\left(\mathrm{CDCl}_{3}\right)$. Acetonitrile (HPLC, Prolabo) and tetrabutylammonium hexafluorophosphate $\left(\left[{ }^{\mathrm{n}} \mathrm{Bu}_{4} \mathrm{~N}\right]\left[\mathrm{PF}_{6}\right]\right.$, Acros) were used to prepare solutions for electrochemical measurements.

Synthesis method and complexes characterization. All synthetic manipulations were carried out under an atmosphere of dry, oxygen-free nitrogen using standard Schlenk techniques. The solvents were dried and distilled under nitrogen atmosphere before use. Elemental analyses were performed with a LECO CHNS-932 Elemental Microanalyzer (from Universidad Autónoma de Madrid). The analytical data for the new compounds were obtained from crystalline samples when possible. In some cases the data were reasonably accurate, but in others the agreement of calculated and found values for carbon was $>0.4 \%$, so that solvent molecules were introduced in the molecular formulae to improve agreement. IR spectra were recorded on a Jasco FT/IR-4200 spectrophotometer (4000-400 $\mathrm{cm}^{-1}$ range) with Single Reflection ATR Measuring Attachment. FAB Mass spectra (position of the peaks in DA) were recorded with an Autospec spectrometer. The isotopic distribution of the heaviest set of peaks matched very closely that calculated for the formulation of the complex cation in every case. NMR samples were prepared under a nitrogen atmosphere by dissolving the suitable amount of compound in $0.5 \mathrm{~mL}$ of the respective oxygen-free deuterated solvent and the spectra were recorded at $298 \mathrm{~K}$ (unless otherwise stated) on a Varian Unity Inova-400 (399.94 MHz for ${ }^{1} \mathrm{H}$; 161.9 MHz for ${ }^{31} \mathrm{P}$; $376.28 \mathrm{MHz}$ for ${ }^{19} \mathrm{~F}$; $100.6 \mathrm{MHz}$ for ${ }^{13} \mathrm{C}$ ). 
Typically, 1D ${ }^{1} \mathrm{H}$ NMR spectra were acquired with 32 scans into $32 \mathrm{k}$ data points over a spectral width of $16 \mathrm{ppm} .{ }^{1} \mathrm{H}$ and ${ }^{13} \mathrm{C}\left\{{ }^{1} \mathrm{H}\right\}$ chemical shifts were internally referenced to TMS via the residual ${ }^{1} \mathrm{H}$ and ${ }^{13} \mathrm{C}$ signals of the corresponding solvents, $\mathrm{CDCl}_{3}(\delta=7.26 \mathrm{ppm}$ and $\delta=77.16 \mathrm{ppm})$ and $\left(\mathrm{CD}_{3}\right)_{2} \mathrm{SO}(\delta=$ $2.50 \mathrm{ppm}$ and $\delta=39.52 \mathrm{ppm})$, according to the values reported by Fulmer et al. ${ }^{65}$ Chemical shift values are reported in ppm and coupling constants $(J)$ in Hertz. The splitting of proton resonances in the reported ${ }^{1} \mathrm{H}$ NMR data is defined as $\mathrm{s}=$ singlet, $\mathrm{d}=$ doublet, $\mathrm{t}=$ triplet, $\mathrm{st}=$ pseudotriplet, $\mathrm{q}=$ quartet, sept $=$ septet, $\mathrm{m}=$ multiplet, $\mathrm{bs}=$ broad singlet. $2 \mathrm{D} \mathrm{NMR}$ spectra such as ${ }^{1} \mathrm{H}-{ }^{1} \mathrm{H}$ gCOSY,${ }^{1} \mathrm{H}-{ }^{1} \mathrm{H}$ NOESY,${ }^{1} \mathrm{H}-{ }^{13} \mathrm{C}$ gHSQC and ${ }^{1} \mathrm{H}^{13} \mathrm{C}$ gHMBC were recorded using standard pulse sequences. The probe temperature $( \pm 1 \mathrm{~K})$ was controlled by a standard unit calibrated with methanol as a reference. All NMR data processing was carried out using MestReNova version 10.0.2. Characterization data have been moved to the Supporting Information. TGA measurements were performed on a TGA Q50 V20.10 instrument from 25 to $800{ }^{\circ} \mathrm{C}$ in a flowing mixture of nitrogen/air $(60: 40 \mathrm{~mL} / \mathrm{min})$ at a heating rate of $10^{\circ} \mathrm{C} \cdot \mathrm{min}^{-1}$.

X-ray Crystallography. A summary of crystal data collection and refinement parameters for compounds $[4]\left[\mathrm{PF}_{6}\right]$ and $[5]\left[\mathrm{PF}_{6}\right]$ are given in Table S1. Single crystals of $[4]\left[\mathrm{PF}_{6}\right]$ and $[5]\left[\mathrm{PF}_{6}\right]$ were mounted on a glass fiber and transferred to a Bruker X8 APEX II CCD-based diffractometer equipped with a graphite monochromated $\mathrm{MoK} \alpha$ radiation source $(\lambda=$ $0.71073 \AA$ ). The highly redundant datasets were integrated using SAINT ${ }^{66}$ and corrected for Lorentz and polarization effects. The absorption correction was based on the function fitting to the empirical transmission surface as sampled by multiple equivalent measurements with the program SADABS. ${ }^{67}$

The software package SHELXTL (version 6.10) ${ }^{68}$ was used for space group determination, structure solution, and refinement by full-matrix least-squares methods based on $F^{2}$. A successful solution by direct methods provided most nonhydrogen atoms from the E-map. The remaining non-hydrogen atoms were located in an alternating series of least-squares cycles and difference Fourier maps. All non-hydrogen atoms were refined with anisotropic displacement coefficients. Hydrogen atoms were placed using a "riding model" and included in the refinement at calculated positions. CCDC reference numbers for $[4]\left[\mathrm{PF}_{6}\right]$ and $[5]\left[\mathrm{PF}_{6}\right]$ are 1519073 and 1519074 respectively.

The thermal ellipsoid molecular structures depicted in Figure 2 were plotted using the ORTEP-III program for crystal structure illustrations. ${ }^{9}$

Electrochemical measurements. Electrochemical measurements were performed using a customized SPELEC (DropSens) equipment, a commercial fully integrated synchronized spectroelectrochemical device, that includes a bipotentiostat/galvanostat controlled by DropView (DropSens). All experiments were carried out using a three-electrode cell using a glassy carbon-disc with a diameter of $3 \mathrm{~mm}$ as working electrode, a platinum-wire as auxiliary electrode, and a silverwire pseudo-reference electrode. Oxygen was removed from the solution by bubbling argon during 10 minutes and keeping the current of argon along the whole experiment. The formal potentials were determined by cyclic voltammetry (CV), scanning the potential at a scan rate of $0.15 \mathrm{~V} \mathrm{~s}^{-1}$. All potentials were referred to the redox pair ferrocene/ferrocenium $\left(\mathrm{Fc} / \mathrm{Fc}^{+}\right)$ took as internal standard. All voltammetric experiments were started and finished at a potential of $-0.46 \mathrm{~V}$ and performed in a clockwise direction. Acetonitrile solutions of the complexes $\left(10^{-3} \mathrm{M}\right)$ were used in the presence of $0.1 \mathrm{M}\left[{ }^{\mathrm{n}} \mathrm{Bu}_{4} \mathrm{~N}\right]\left[\mathrm{PF}_{6}\right]$ as supporting electrolyte.

Photophysical characterization. The UV-Vis absorbance spectra were measured with a Secomam XT5 UVi Light spectrometer. Quantum yields and PL emission spectra were recorded using a Hamamatsu absolute quantum yield C9920, whereas excited-state lifetimes were determined using a Hamamatsu Compact fluorescence lifetime spectrometer C11367 (Quantaurus-Tau).

Computational details. Density functional calculations (DFT) were carried out with the D.01 revision of the Gaussian 09 program package. ${ }^{70}$ The Becke's three-parameter B3LYP exchange-correlation functional ${ }^{71,72}$ was used, together with the $6-31 \mathrm{G}^{* *}$ basis set for $\mathrm{C}, \mathrm{H}, \mathrm{N}$, and $\mathrm{S},{ }^{73}$ and the "double- $\zeta$ " quality LANL2DZ basis set for the Ir atom. ${ }^{74}$ Relativistic effects were accounted for by means of an effective core potential (ECP), which was used to replace the inner core electrons of Ir. The geometries of both the singlet ground electronic state $\left(\mathrm{S}_{0}\right)$ and the lowest-energy triplet state $\left(\mathrm{T}_{1}\right)$ were fully optimized for cations $[\mathbf{1}]^{+}$to $[\mathbf{5}]^{+}$. In addition, the radical neutral species $[\mathbf{1}]^{-}-[\mathbf{5}]^{-}$resulting from the reduction of $[\mathbf{1}]^{+}-[\mathbf{5}]^{+}$ were also optimized in a doublet electronic state configuration $\left(D_{0}\right)$. No symmetry restrictions were imposed. The geometries of $[\mathbf{1}]^{+}-[\mathbf{5}]^{+}$in the $T_{1}$ state and of $[\mathbf{1}]^{\circ}-[\mathbf{5}]^{\circ}$ in the $\mathrm{D}_{0}$ state were calculated at the spin-unrestricted UB3LYP level using spin multiplicity of three and two, respectively. All the calculations were performed in the presence of the solvent (acetonitrile). Solvent effects were considered within the self-consistent reaction field (SCRF) theory using the polarized continuum model (PCM) approach. ${ }^{75,76,77}$ Time-dependent DFT (TDDFT) ${ }^{78,79,80}$ calculations of the lowest-lying 5 triplet states of the complexes were performed in the presence of the solvent at the minimum-energy geometry optimized for the ground state. The geometries of the first and second triplet excited states of $[\mathbf{1}]^{+}$were first optimized at the TD-DFT level, and then reoptimized at the UB3LYP level to compare with the results obtained for $T_{1}$ from DFT calculations for all the other complexes.

Device preparation. LECs were prepared on top of a patterned indium tin oxide (ITO, $15 \Omega$ square $^{-1}$ ) coated glass substrate (www.naranjosubstrates.com) previously cleaned as follows: a) sonication with soap, b) deionized water, c) isopropanol, and d) $\mathrm{UV}-\mathrm{O}_{3}$ lamp for $20 \mathrm{~min}$. The thickness of the films was determined with an Ambios XP-1 profilometer. Prior to the deposition of the emitting layer, $80 \mathrm{~nm}$ of poly(3,4-ethylenedioxythiophene):poly-(styrenesulfonate) (PEDOT:PSS) (CLEVIOSTM P VP AI 4083, aqueous dispersion, $1.3-1.7 \%$ solid content, Heraeus) was coated in order to avoid the formation of pinholes and to increase the reproducibility of the cells. The emitting layer $(100 \mathrm{~nm})$ was prepared by spin-coating of a MeCN solution consisting of the iTMC with the addition of the ionic liquid (IL) 1-butyl-3methylimidazolium hexafluorophosphate $[\mathrm{Bmim}]\left[\mathrm{PF}_{6}\right]$ (> $98.5 \%$, Sigma-Aldrich) in a $4: 1$ molar ratio (iTMC:IL). The devices were then transferred to an inert atmosphere glovebox $\left(<0.1\right.$ ppm $\mathrm{O}_{2}$ and $\mathrm{H}_{2} \mathrm{O}$, MBraun) and annealed during 1 hour at $100{ }^{\circ} \mathrm{C}$. Finally, a layer $(70 \mathrm{~nm})$ of aluminium (the top electrode) was thermally evaporated onto the devices using an Edwards Auto500 evaporator integrated in the inert atmos- 
phere glovebox. The area of the device was $6.5 \mathrm{~mm}^{2}$. The devices were not encapsulated and were characterized inside the glovebox at room temperature.

Device characterization. The device lifetime was measured by applying a pulsed current and monitoring the voltage and the luminance versus time by a True Colour Sensor MAZeT (MTCSiCT Sensor) with a Botest OLT OLED Lifetime-Test System. The average current density is determined by multiplying the peak current density by the time-on time and dividing by the total cycle time. The average luminance is directly obtained by taking the average of the obtained photodiode

\section{REFERENCES}

1 Sun, Y.; Giebink, N. C.; Kanno, H.; Ma, B.; Thompson M. E.; Forrest S. R. Management of Singlet and Triplet Excitons for Efficient White Organic Light-Emitting Devices. Nature 2006, 440, 908-912.

2 Reineke, S.; Lindner, F.; Schwartz, G.; Seidler, N.; Walzer, K.; Lüssemand B.; Leo K. White Organic Light-Emitting Diodes with Fluorescent Tube Efficiency. Nature 2009, 459, 234-238.

3 Jou, J.-H.; Kumar, S.; Agrawal, A.; Lia, T.-H.; Sahoo, S. Approaches for Fabricating High Efficiency Organic Light Emitting Diodes. J. Mater. Chem. C 2015, 3, 2974-3002.

4 Pei, Q.; Yu, G.; Zhang, C.; Yang Y.; Heeger, A. J. Polymer Light-Emitting Electrochemical Cells. Science 1995, 269, 1086-1088.

5 Costa, R. D.; Ortí, E.; Bolink, H. J.; Monti, F.; Accorsi G.; Armaroli, N. Luminescent Ionic Transition-Metal Complexes for Light-Emitting Electrochemical Cells. Angew. Chem. Int. Ed. 2012, 51, 8178-8211.

6 Sandstrom, A.; Edman, L. Towards High-Throughput Coating and Printing of Light-Emitting Electrochemical Cells: A Review and Cost Analysis of Current and Future Methods. Energy Technol. 2015, 3, 329-339.

7 Fresta, E.; Costa, R. D. Beyond traditional light-emitting electrochemical cells - a review of new device designs and emitters. J. Mater. Chem. C, 2017, 5, 5643-5675

8 Kaihovirta, N.; Larsen, C.; Edman, L. Improving the Performance of Light-Emitting Electrochemical Cells by Optical Design. ACS Appl. Mater. Interfaces, 2014, 6, 29402947.

9 Jenatsch, S.; Wang, L.; Bulloni, M.; Véron, A. C.; Ruhstaller, B.; Altazin, S.; Nüesch, F.; Hany R. Doping Evolution and Junction Formation in Stacked Cyanine Dye LightEmitting Electrochemical Cells. ACS Appl. Mater. Interfaces, 2016, 8, 6554-6562.

10 Tang, S.; Edman, L. Light-Emitting Electrochemical Cells: A Review on Recent Progress. Top Curr Chem (Z) 2016, 374,40 .

${ }^{11}$ Henwood, A. F.; Zysman-Colman, E. Luminescent Iridium Complexes Used in Light-Emitting Electrochemical Cells (LEECs). Top Curr Chem (Z) 2016, 374, 36.

$12 \mathrm{Su}, \mathrm{H}$. - C.; Hsu, J. -H. Improving the carrier balance of light-emitting electrochemical cells based on ionic transition metal complexes. Dalton. Trans., 2015, 44, 8330-8345 results and correlating it to the value of a luminance meter. The current efficiency is obtained by dividing the average luminance by the average current density. The electroluminescent (EL) spectra were measured using an Avantes AvaSpec2048 Fiber Optic Spectrometer during device lifetime measurement.

Supporting Information. Synthesis of cationic iridium complexes, 2D 1H-1H NOESY spectra, TGA measurements, Xray crystal structures, excited-state lifetimes, and theoretical calculations.

${ }^{13}$ Costa, R. D.; Ortí E.; Bolink, H. J. Recent Advances in Light-Emitting Electrochemical Cells. Pure Appl. Chem. 2011, 83, 2115-2128.

${ }^{14}$ Slinker, J.; Bernards, D.; Houston, P. L.; Abruña, H. D.; Bernhard S.; Malliaras G. G. Solid-State Electroluminescent Devices Based on Transition Metal Complexes. Chem. Commun. 2003, 2392-2399.

${ }^{15}$ Meier, S. B.; Tordera, D.; Pertegás, A.; Roldán-Carmona, C.; Ortí, E.; Bolink H. J. Light-Emitting Electrochemical Cells: Recent Progress and Future Prospects. Mater. Today 2014, 17, 217-223.

${ }^{16}$ Ma, D.; Tsuboi, T.; Qiu, Y.; Duan, L. Recent Progress in Ionic Iridium(III) Complexes for Organic Electronic Devices. Adv. Mater. 2017, 29, 1603253.

${ }^{17}$ Namanga, J. E.; Gerlitzki, N.; Mudring A.-V. Scrutinizing Design Principles toward Efficient, Long-Term Stable Green Light-Emitting Electrochemical Cells. Adv. Funct. Mater. 2017, 27, 1605588.

${ }^{18}$ Chi Y.; Chou, P.-T. Transition-Metal Phosphors with Cyclometalating Ligands: Fundamentals and Applications. Chem. Soc. Rev. 2010, 39, 638-655.

19 Hu, T.; He, L.; Duan L.; Qiu, Y. Solid-State Light-Emitting Electrochemical Cells based on Ionic Iridium(III) Complexes. J. Mater. Chem. 2012, 22, 4206-4215.

20 Su, H.-C.; Fang, F.-C.; Hwu, T.-Y.; Hsieh, H.-H.; Chen, H.F.; Lee, G.-H.; Peng, S.-M.; Wong, K.-T.; Wu C.-C. Highly Efficient Orange and Green Solid-State Light-Emitting Electrochemical Cells Based on Cationic IrIII Complexes with Enhanced Steric Hindrance. Adv. Funct. Mater. 2007, 17, 1019-1027.

${ }^{21}$ Bolink, H. J.; Coronado, E.; Costa, R. D.; Lardiés N.; Ortí E. Near-Quantitative Internal Quantum Efficiency in a Light-Emitting Electrochemical Cell. Inorg. Chem. 2008, 47, 9149-9151.

${ }^{22}$ Tordera, D; Frey, J.; Vonlanthen, D.; Constable, E.; Pertegás, A.; Ortí, E.; Bolink, H. J.; Baranoff, E.; Nazeeruddin M. K. Low Current Density Driving Leads to Efficient, Bright and Stable Green Electroluminescence. Avd. Energy Mater. 2013, 3, 1338-1343.

${ }^{23}$ Tordera, D.; Meier, S.; Lenes, M.; Costa, R. D.; Ortí, E.; Sarfert, W.; Bolink, H. J. Simple, Fast, Bright, and Stable Light Sources. Adv. Mater. 2012, 24, 897-900.

${ }^{24}$ Bünzli, A. M.; Constable, E. C.; Housecroft, C. E.; Prescimone, A; Zampese, J. A.; Longo, G; Gil-Escrig, L.; Pertegás, A.; Ortí, E.; Bolink, H. J. Exceptionally LongLived Light-Emitting Electrochemical Cells: Multiple Intra- 
Cation $\pi$-Stacking Interactions in $\left[\operatorname{Ir}\left(\mathrm{C}^{\wedge} \mathrm{N}\right)_{2}\left(\mathrm{~N}^{\wedge} \mathrm{N}\right)\right]\left[\mathrm{PF}_{6}\right]$ Emitters. Chem. Sci. 2015, 6, 2843-2852.

${ }^{25}$ Huang, P.-Ch.; Krucaite, G.; Su H.-Ch.; Grigalevicius S. Incorporating a Hole-Transport Material into the Emissive Layer of Solid-State Light-Emitting Electrochemical Cells to Improve Device Performance. Phys. Chem. Chem. Phys. 2015, 17, 17253-17259.

${ }^{26}$ Costa, R. D.; Pertegás, A.; Ortí, E.; Bolink H. J. Improving the Turn-On Time of Light-Emitting Electrochemical Cells without Sacrificing their Stability. Chem. Mater. 2010, 22, 1288-1290.

${ }^{27}$ Shen, Y.; Kuddes, D. D.; Naquin, C. A.; Hesterberg, T. W.; Kusmierz, C.; Holliday, B. J.; Slinker, J. D. Improving Light-Emitting Electrochemical Cells with Ionic Additives. Appl. Phys. Lett. 2013, 102, 203305.

2 Suhr, K. J.; Bastatas, L. D.; Shen, Y.; Mitchell, L. A.; Holliday B. J.; Slinker. J. D. Enhanced Luminance of Electrochemical Cells with a Rationally Designed Ionic Iridium Complex and an Ionic Additive. ACS Appl. Mater. Interfaces, 2016, 8, 8888-8892.

${ }^{29}$ Costa, R. D.; Ortí, E.; Bolink, H. J.; Graber, S.; Housecroft, C. E.; Constable, E. C. Intramolecular $\pi$-Stacking in a Phenylpyrazole-Based Iridium Complex and Its Use in LightEmitting Electrochemical Cells. J. Am. Chem. Soc. 2010, $132,5978-5980$.

${ }^{30}$ Costa, R. D.; Ortí, E.; Bolink, H. J.; Graber, S.; Housecroft, C. E.; Constable, E. C. Efficient and Long-Living LightEmitting Electrochemical Cells. Adv Funct Mater 2010, 20, 1511-1520.

${ }^{31}$ Rothe, C.; Chiang, C.-J.; Jankus, V.; Abdullah, K.; Zeng, X.; Jitchati, R.; Batsanov, A. S.; Bryce M. R.; Monkman, A. P. Ionic Iridium(III) Complexes with Bulky Side Groups for Use in Light Emitting Cells: Reduction of Concentration Quenching. Adv. Funct. Mater. 2009, 19, 2038-2044.

${ }^{32}$ Pla, P.; Junquera-Hernández, J. M.; Bolink, H. J.; Ortí, E. Emission Energy of Azole-Based Ionic Iridium(III) Complexes: a Theoretical Study. Dalton Trans. 2005, 44, 84978505 .

33 Ladouceur, S.; Fortin, D.; Zysman-Colman, E. Enhanced Luminescent Iridium(III) Complexes Bearing Aryltriazole Cyclometallated Ligands. Inorg. Chem. 2011, 50, 1151411526.

34 Tamayo, A. B.; Garon, S.; Sajoto, T.; Djurovich, P. I.; Tsyba, I.M.; Bau, R.; Thompson, M. E. Cationic Biscyclometalated Iridium(III) Diimine Complexes and Their Use in Efficient Blue, Green, and Red Electroluminescent Devices. Inorg. Chem. 2005, 44, 8723-8732.

35 Fernández-Hernández, J. M.; Yang, C.-H.; Beltrán, J. I.; Lemaur, V.; Polo, F.; Fröhlich, R.; Cornil, J.; De Cola, L. Control of the Mutual Arrangement of Cyclometalated Ligands in Cationic Iridium(III) Complexes. Synthesis, Spectroscopy, and Electroluminescence of the Different Isomers. J. Am. Chem. Soc. 2011, 133, 10543-10558.

${ }^{36}$ Monti, F.; Baschieri, A.; Gualandi, I.; Serrano-Pérez, J. J.; Junquera-Hernández, J. M.; Tonelli, D.; Mazzanti, A.; Muzzioli, S.; Stagni, S.; Roldan-Carmona, C.; Pertegás, A.; Bolink, H. J.; Ortí, E.; Sambri, L.; Armaroli, N. Iridium(III)
Complexes with Phenyl-tetrazoles as Cyclometalating Ligands. Inorg. Chem. 2014, 53, 7709-7721.

Fernandez-Hernandez, J. M.; Ladouceur, S.; Shen, Y.; Iordache, A.; Wang, X.; Donato, L.; Gallagher-Duval, S.; de Anda Villa, M.; Slinker, J. D.; De Cola L.; ZysmanColman. E. Blue Light Emitting Electrochemical Cells Incorporating Triazole-based Luminophores. J. Mater. Chem. $C, \mathbf{2 0 1 3}, 1,7440-7452$.

${ }^{38}$ He, L.; Qiao, J.; Duan, L.; Dong, G.; Zhang, D.; Wang, L.; Qiu Y. Toward Highly Efficient Solid-State White LightEmitting Electrochemical Cells: Blue-Green to Red Emitting Cationic Iridium Complexes with Imidazole-Type Ancillary Ligands. Adv. Funct. Mater. 2009, 19, 2950-2960.

${ }^{39}$ He, L.; Duan, L.; Qiao, J.; Zhang, D.; Wang, L.; Qiu, Y. Enhanced Stability of Blue-Green Light-Emitting Electrochemical Cells Based on a Cationic Iridium Complex with 2-(1-Phenyl-1H-Pyrazol-3-yl)Pyridine as the Ancillary Ligand. Chem. Commun. 2011, 47, 6467-6469.

${ }^{40}$ Sunesh, C. D.; Mathai, G.; Choe, Y. Constructive Effects of Long Alkyl Chains on the Electroluminescent Properties of Cationic Iridium Complex-Based Light-Emitting Electrochemical Cells. ACS Appl. Mater. Interfaces 2014, 6, 17416-17425.

${ }^{41}$ Sunesh, C. D.; Mathai, G.; Choe, Y. Green and Blue-Green Light-Emitting Electrochemical Cells Based on Cationic Iridium Complexes with 2-(4-Ethyl-2-Pyridyl)-1HImidazole Ancillary Ligand. Org. Electron. 2014, 15, 667674.

${ }^{42}$ Sunesh, C. D.; Choe, Y. Synthesis and Characterization of Cationic Iridium Complexes for the Fabrication of Green and Yellow Light-Emitting Devices. Mater. Chem. Phys. 2015, 156, 206-213.

43 Jeona, Y.; Sunesh, C. D.; Chitumallab, R. K.; Jangb, J.; Choe, Y. Fabrication of Efficient Light-Emitting Electrochemical Cells Utilizing Thiazole- and Pyridine-Based Cationic Iridium Complexes. Electrochim. Acta 2016, 195, $112-123$.

${ }^{44}$ Sun, H.; Liu, S.; Lin, W.; Zhang, K. Y.; Lv, W.; Huang, X.; Huo, F.; Yang, H.; Jenkins, G.; Zhao, Q.; Huang, W. Smart Responsive Phosphorescent Materials for Data Recording and Security Protection. Nat. Commun. 2014, 5, 3601.

${ }^{45}$ Nonoyama, M. Benzo[h]quinolin-10-yl-N Iridium(III) Complexes. Bull. Chem. Soc. Jpn. 1974, 47, 767-768.

${ }^{46}$ Schneider, G. E.; Pertegás, A.; Constable, E. C.; Housecroft, C. E.; Hostettler, N.; Morris, C. D.; Zampese, J. A.; Bolink, H. J.; Junquera-Hernández, J. M.; Ortí, E.; Sessolo, M. Bright and Stable Light-Emitting Electrochemical Cells Based on an Intramolecularly $\pi$-Stacked, 2-NaphthylSubstituted Iridium Complex. J. Mater. Chem. C 2014, 2, 7047-7055.

${ }^{47}$ Meng, S.; Jung, I.; Feng, J.; Scopelliti, R.; Di Censo, D.; Grätzel, M.; Nazeeruddin, M. K.; Baranoff, E. Bis(pyrazol1-yl)Methane as Non-Chromophoric Ancillary Ligand for Charged Bis-Cyclometalated Iridium(III) Complexes. Eur. J. Inorg. Chem. 2012, 2012, 3209-3215.

48 Tsuboyama, A.; Iwawaki, H.; Furugori, M.; Mukaide, T.; Kamatani, J.; Igawa, S.; Moriyama, T.; Miura, S.; Takigu- 
chi, T.; Okada, S.; Hoshino M.; Ueno, K. Homoleptic Cyclometalated Iridium Complexes with Highly Efficient Red Phosphorescence and Application to Organic LightEmitting Diode. J. Am. Chem. Soc. 2003, 125, 1297112979.

49 Chen, P.; Meyer, T. J. Medium Effects on Charge Transfer in Metal Complexes. Chem. Rev. 1998, 98, 1439-1478.

${ }^{50}$ Ladouceur, S.; Fortin, D.; Zysman-Colman, E. Role of Substitution on the Photophysical Properties of 5,5'-Diaryl2,2'-bipyridine (bpy*) in $\left[\operatorname{Ir}(\mathrm{ppy}) 2\left(\mathrm{bpy}^{*}\right)\right] \mathrm{PF}_{6}$ Complexes: A Combined Experimental and Theoretical Study. Inorg. Chem. 2010, 49, 5625-5641.

${ }^{51}$ Ertl, C. D.; Cerdá, J.; Junquera-Hernández, J. M.; Pertegás, A.; Bolink, H. J.; Constable, E. C.; Neuburger, M.; Ortí, E.; Housecroft, C. E. Colour Tuning by the Ring Roundabout: $\left[\operatorname{Ir}\left(\mathrm{C}^{\wedge} \mathrm{N}\right)_{2}\left(\mathrm{~N}^{\wedge} \mathrm{N}\right)\right]^{+}$Emitters with Sulfonyl-Substituted Cyclometallating Ligands. RSC Adv. 2015, 5, 42815-42827.

52 Ertl, C. D.; Gil-Escrig, L.; Cerdá, J.; Pertegás, A.; Bolink, H. J.; Junquera-Hernández, J. M.; Prescimone, A.; Neuburger, M.; Constable, E. C.; Ortí, E.; Housecroft, C. E., Regioisomerism in Cationic Sulfonyl-Substituted $\left[\operatorname{Ir}\left(\mathrm{C}^{\wedge} \mathrm{N}\right)_{2}\left(\mathrm{~N}^{\wedge} \mathrm{N}\right)\right]^{+}$Complexes: its Influence on Photophysical Properties and LEC Performance. Dalton Trans. 2016, 45, 11668-11681.

${ }^{53}$ Costa, R. D.; Ortí, E.; Bolink, H. J.; Graber, S.; Schaffner, S.; Neuburger, M.; Housecroft C. E.; Constable, E. C., Archetype Cationic Iridium Complexes and Their Use in Solid-State Light-Emitting Electrochemical Cells. Adv. Funct. Mater. 2009, 19, 3456-3463.

${ }^{54}$ Baranoff, E.; Bolink, H. J.; Constable, E. C.; Delgado, M.; Häussinger, D.; Housecroft, C. E.; Nazeeruddin, M. K.; Neuburger, M.; Ortí, E.; Schneider, G. E.; Tordera, D.; Walliser R. M.; Zampese, J. A. Tuning the Photophysical Properties of Cationic Iridium(III) Complexes Containing Cyclometallated 1-(2,4-Difluorophenyl)-1H-Pyrazole Through Functionalized 2,2'-Bipyridine Ligands: Blue but not Blue Enough. Dalton Trans. 2013, 42, 1073-1087.

${ }^{55}$ Meier, S. B.; Sarfert, W.; Junquera-Hernández, J. M.; Delgado, M.; Tordera, D.; Ortí, E.; Bolink, H. J.; Kessler, F.; Scopelliti, R.; Grätzel M.; Nazeeruddin, M. K. A DeepBlue Emitting Charged bis-Cyclometallated Iridium(III) Complex for Light-Emitting Electrochemical Cells. J. Mater. Chem. C 2013, 1, 58-68.

${ }^{56}$ De Angelis, F.; Fantacci, S.; Evans, N.; Klein, C.; Zakeeruddin, S. M.; Moser, J.-E.; Kalyanasundaram, K.; Bolink, H. J.; Grätzel M.; Nazeeruddin, M. K. Controlling Phosphorescence Color and Quantum Yields in Cationic Iridium Complexes: A Combined Experimental and Theoretical Study. Inorg. Chem. 2007, 46, 5989-6001.

57 Tordera, D.; Bünzli, A. M.; Pertegás, A.; JunqueraHernández, J. M.; Constable, E. C.; Zampese, J. A.; Housecroft, C. E.; Ortí E.; Bolink, H. J. Efficient Green-LightEmitting Electrochemical Cells Based on Ionic Iridium Complexes with Sulfone-Containing Cyclometalating Ligands. Chem. Eur. J. 2013, 19, 8597-8609.

${ }^{58}$ Parker S. T.; Slinker, J. D.; Lowry, M. S.; Cox, M. P.; Bernhard, S.; Malliaras, G. G. Improved Turn-on Times of
Iridium Electroluminescent Devices by Use of Ionic Liquids. Chem. Mater. 2005, 17, 3187-3190.

59 Tordera, D.; Pertegás, A.; Shavaleev, N. M.; Scopelliti, R; Ortí, E.; Bolink, H. J.; Baranoff, E.; Gratzel, M.; Nazeeruddin, M. K. Efficient Orange Light-Emitting Electrochemical Cells. J. Mater. Chem. 2012, 22, 19264-19268.

${ }^{60}$ Nonoyama, M. Chelating C-Metallation of NPhenylpyrazole with Rhodium(III) and Iridium(III). J. Organomet. Chem. 1975, 86, 263-267.

${ }^{61}$ Sprouse, S.; King, K. A.; Spellane, P. J.; Watts, R. J. Photophysical Effects of Metal-Carbon $\sigma$ Bonds in Orthometalated Complexes of Iridium(III) and Rhodium(III). $J$. Am. Chem. Soc. 1984, 106, 6647-6653.

${ }^{62}$ Chiswell, B.; Lions, F.; Morris, B. S. Bidentate Chelate Compounds. III. Metal Complexes of Some PyridylImidazole Derivatives. Inorg. Chem. 1964, 3, 110-113.

63 Stupka, G.; Gremaud, L.; Williams, A. F. Control of Redox Potential by Deprotonation of Coordinated 1H-Imidazole in Complexes of 2-(1H-Imidazol-2-yl)pyridine. Helv. Chim. Acta 2005, 88, 487-495.

${ }^{64}$ Zeng, F. L.; Yu, Z. K. Exceptionally Efficient Unsymmetrical Ruthenium(II) NNN Complex Catalysts Bearing a Pyridyl-Based Pyrazolyl-Imidazolyl Ligand for Transfer Hydrogenation of Ketones. Organometallics 2008, 27, 2898-2901.

${ }^{65}$ Fulmer, G. R.; Miller, A. J. M.; Sherden, N. H.; Gottlieb, H. E.; Nudelman, A.; Stoltz, B. M.; Bercaw, J. E.; Goldberg, K. I. NMR Chemical Shifts of Trace Impurities: Common Laboratory Solvents, Organics, and Gases in Deuterated Solvents Relevant to the Organometallic Chemist. Organometallics 2011, 29, 2176-2179.

${ }^{66}$ Bruker SAINT, Version 8.37, Bruker AXS Inc., 2015.

${ }^{67}$ Sheldrick, G. M. SADABS A Program for Empirical Absorption Correction. Version 2004/1; University of Göttingen, Göttingen, Germany, 2004.

${ }^{68}$ WINGX, Version 2013.3, Farrugia, L. J. J. Appl. Crystal$\log r$. 1999, 32, 837-838.

$9 \mathrm{r}$

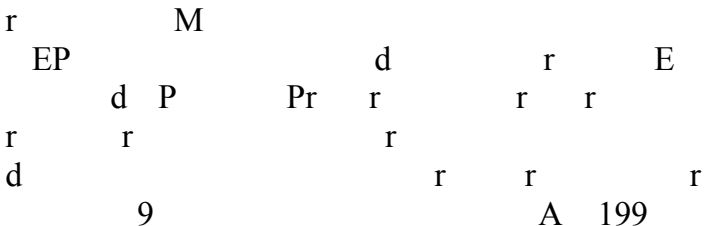

${ }^{70}$ Gaussian 09, Revision D.01, Frisch, M. J.; Trucks, G. W.; Schlegel, H. B.; Scuseria, G. E.; Robb, M. A.; Cheeseman, J. R.; Scalmani, G.; Barone, V.; Mennucci, B.; Petersson, G. A.; Nakatsuji, H.; Caricato, M.; Li, X.; Hratchian, H. P.; Izmaylov, A. F.; Bloino, J.; Zheng, G.; Sonnenberg, J. L.; Hada, M.; Ehara, M.; Toyota, K.; Fukuda, R.; Hasegawa, J.; Ishida, M.; Nakajima, T.; Honda, Y.; Kitao, O.; Nakai, H.; Vreven, T.; Montgomery, J. A., Jr.; Peralta, J. E.; Ogliaro, F.; Bearpark, M.; Heyd, J. J.; Brothers, E.; Kudin, K. N.; Staroverov, V. N.; Kobayashi, R.; Normand, J.; Raghavachari, K.; Rendell, A.; Burant, J. C.; Iyengar, S. S.; Tomasi, J.; Cossi, M.; Rega, 
N.; Millam, J. M.; Klene, M.; Knox, J. E.; Cross, J. B.; Bakken, V.; Adamo, C.; Jaramillo, J.; Gomperts, R.; Stratmann, R. E.; Yazyev, O.; Austin, A. J.; Cammi, R.; Pomelli, C.; Ochterski, J. W.; Martin, R. L.; Morokuma, K.; Zakrzewski, V. G.; Voth, G. A.; Salvador, P.; Dannenberg, J. J.; Dapprich, S.; Daniels, A. D.; Farkas, Ö.; Foresman, J. B.; Ortiz, J. V.; Cioslowski, J.; Fox, D. J. Gaussian, Inc., Wallingford CT, 2009.

${ }^{71}$ Lee, C.; Yang, W.; Parr, R. G. Development of the Colle-Salvetti Correlation-Energy Formula into a Functional of the Electron Density. Phys. Rev. B: Condens. Matter. Mater. Phys. 1988, 37, 785-789.

72 Becke, A. D. Density Functional Thermochemistry. III. The Role of Exact Exchange. J. Chem. Phys. 1993, 98, 5648-5652.

${ }^{73}$ Francl, M. M.; Pietro, W. J.; Hehre, W. J.; Binkley, J. S.; Gordon, M. S.; DeFrees, D. J.; Pople, J. A. Self Consistent Molecular Orbital Methods. XXIII. A Polarization Type Basis Set for Second Row Elements. $J$. Chem. Phys. 1982, 77, 3654-3665.

${ }^{74}$ Hay P. J.; Wadt, W. R. Ab Initio Effective Core Potentials for Molecular Calculations. Potentials for $\mathrm{K}$ to $\mathrm{Au}$ Including the Outermost Core Orbitals. J. Chem. Phys. 1985, 82, 299-310.

75 Tomasi J.; Persico, M. Molecular Interactions in Solution: An Overview of Methods Based on Continuous Distributions of the Solvent. Chem. Rev. 1994, 94, $2027-$ 2094.

${ }^{76}$ Cramer C. J.; Truhlar, D. G. In Solvent Effects and Chemical Reactivity. Tapia, O.; Bertrán, J. (Eds.); Kluwer, 1996, pp: 1-80.

77 Tomasi, J.; Mennucci, B.; Cammi, R. Quantum Mechanical Continuum Solvation Models. Chem. Rev. 2005, 105, 2999-3094.

${ }^{78}$ Casida, M. E.; Jamorski, C.; Casida, K. C.; Salahub, D. R. Molecular Excitation Energies to High-Lying Bound States from Time-Dependent DensityFunctional Response Theory: Characterization and Correction of the Time-Dependent Local Density Approximation Ionization Threshold. J. Chem. Phys. 1998, 108, 4439-4449.

79 Jamorski, C.; Casida, M. E.; Salahub, D. R. Dynamic Polarizabilities and Excitation Spectra from a Molecular Implementation of Time Dependent Density Functional Response Theory: N2 as a Case Study. J. Chem. Phys. 1996, 104, 5134-5147.

${ }^{80}$ Petersilka, M.; Gossmann, U. J.; Gross, E. K. U. Excitation Energies from Time-Dependent Density-Functional Theory. Phys. Rev. Lett. 1996, 76, 1212-1215. 